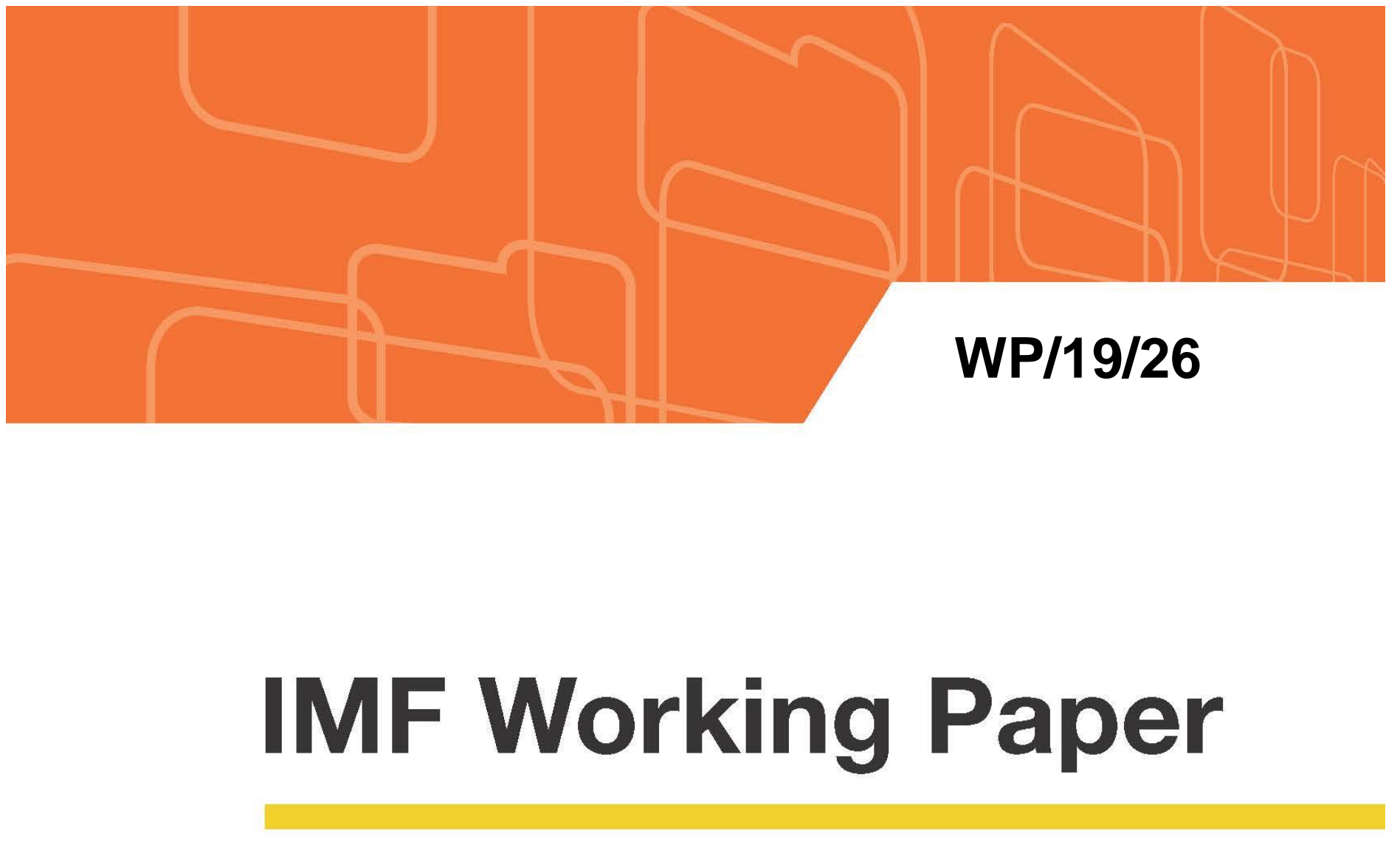

\title{
Importing Inputs for Climate Change Mitigation: The Case of Agricultural Productivity
}

by Rodrigo Garcia-Verdu, Alexis Meyer-Cirkel, Akira Sasahara, and Hans Weisfeld

IMF Working Papers describe research in progress by the author(s) and are published to elicit comments and to encourage debate. The views expressed in IMF Working Papers are those of the author(s) and do not necessarily represent the views of the IMF, its Executive Board, or IMF management. 


\title{
IMF Working Paper
}

\author{
Innovation Lab Unit
}

\section{Importing Inputs for Climate Change Mitigation: The Case of Agricultural Productivity}

\begin{abstract}
Prepared by Rodrigo Garcia-Verdu, Alexis Meyer-Cirkel, Akira Sasahara, and Hans Weisfeld ${ }^{1}$ Authorized for distribution by Tristan Walker
\end{abstract}

February 2019

\section{IMF Working Papers describe research in progress by the author(s) and are published to elicit comments and to encourage debate. The views expressed in IMF Working Papers are those of the author(s) and do not necessarily represent the views of the IMF, its Executive Board, or IMF management.}

\begin{abstract}
This paper estimates agricultural total factor productivity (TFP) in 162 countries between 1991 and 2015 and aims to understand sources of cross-country variations in agricultural TFP levels and its growth rates. Two factors affecting agricultural TFP are analyzed in detail - imported intermediate inputs and climate. We first show that these two factors are independently important in explaining agricultural TFP - imported inputs raise agricultural TFP; and higher temperatures and rainfall shortages impede TFP growth, particularly in low-income countries (LICs). We also provide a new evidence that, within LICs, those with a higher import component of intermediate inputs seem to be more shielded from the negative impacts of weather shocks.
\end{abstract}

JEL Classification Numbers: 013, 047, 054, 056.

Keywords: Agricultural Productivity, TFP, Imported Inputs, Weather Shocks, Climate Change Mitigation, LICs.

Authors’ E-Mail Addresses: rgarciaverdu@imf.org, ameyerirkel@imf.org, sasahara@uidaho.edu, hweisfeld@imf.org

\footnotetext{
${ }^{1}$ The views expressed herein are those of the author and should not be attributed to the IMF, its Executive Board, or its management. The authors thank Manoj Atolia, Alessandro Cantelmo, Irineu de Carvalho Filho, Mai Farid, Gavin Gray, Alain de Janvry, Vera Kehayova, Vladimir Klyuev, Chris Lane, Zhe Liu, Ricardo Marto, Giovanni Melina, Futoshi Narita, Chris Papageorgiou, Saad Quayyum, Giovanni Peri, Robert C. Feenstra, Deborah L. Swenson, Christopher Meissner, and IMF seminar participants for helpful comments. All errors are the authors' responsibility.
} 


\section{Contents}





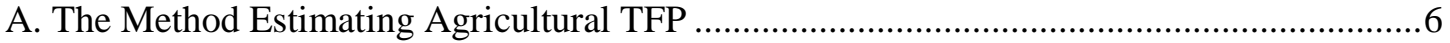

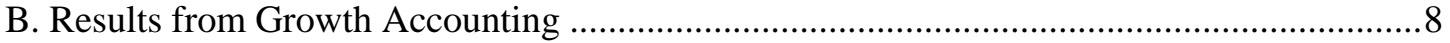

III. Stylized Facts on Imported Inputs, and Weather Shocks .......................................................... 10



A. Imported Inputs and Agricultural TFP Level.................................................................... 13

B. Weather Shocks and Agricultural TFP Growth .............................................................18

C. Importing Inputs Mitigates the Negative Weather Effects: Theory ....................................23

D. Importing Inputs Mitigates the Negative Weather Effects: Evidence.................................25

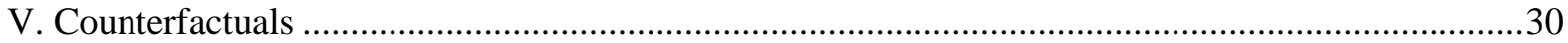

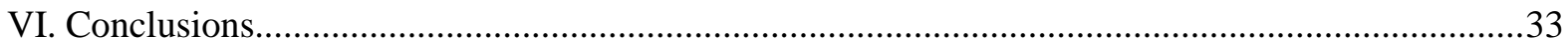

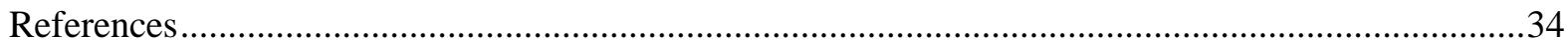

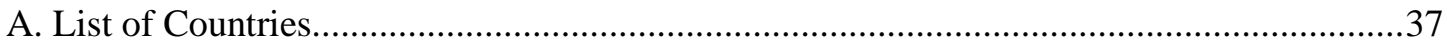

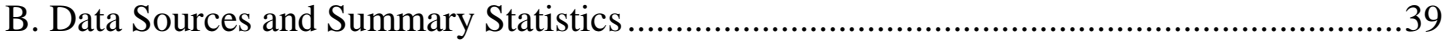

C. Growth Accounting Results ............................................................................................

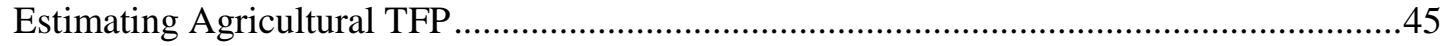

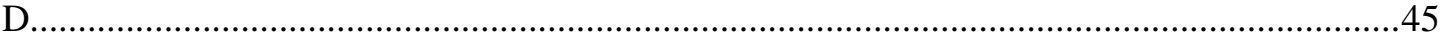

E. Level Effects and Growth Effects ...............................................................................

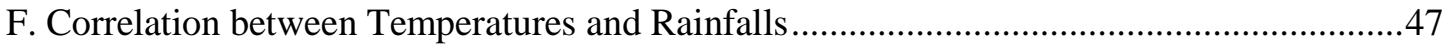

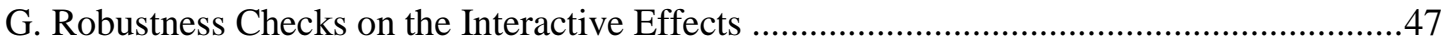

List of Figures

Figure 1: Growth Accounting Results, LICs, 1991-2015 ..............................................................

Figure 2: Agricultural TFP Levels by Income-Level of Countries, 1991-2015 ................................10

Figure 3: The Share of Imported Inputs by Income-Level of Countries, 1990-2015 .........................11

Figure 4: Temperatures and Rainfalls by Income-Level of Countries, 1990-2015 ...........................11

Figure 5: Average Temperatures and Rainfalls in 2015 and their Long-Run Changes since 1990 ......12

Figure 6: Weather Shocks and Annual TFP Growth Rates, LICs...............................................28

Figure 7: Counterfactual TFPs without Change in the Share of Imported Inputs since 1991 ..............30

Figure 8: Counterfactual TFPs without Weather Shocks, LICs ........................................................ 31

\section{List of Tables}

Table 1: Growth Accounting Results, Countries Grouped by Income Level, 1991-2015 ...................8

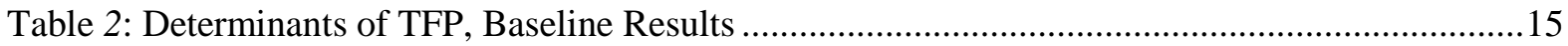



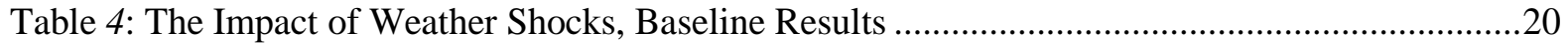

Table 5: The Impact of Weather Shocks, Robustness Checks .........................................................22

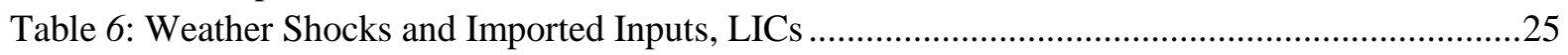

Table 7: Weather Shocks and Imported Inputs, LICs, Robustness Checks .......................................27

Table 8: Actual Agricultural Value-Added and Counterfactual Value-Added under Scenario 1.........32 


\section{INTRODUCTION}

Agricultural productivity, as measured by total factor productivity (TFP), remains far below in low-income countries (LICs) compared to the levels registered in more advanced economies. Productivity in the agricultural sector is significantly lower than in the non-agricultural sector, and this difference is greater in LICs than in developed economies (Adamopoulos and Restuccia, 2018). It is thus not surprising that accelerations in agricultural TFP growth have often preceded episodes of aggregate economic growth (McArthur and McCord, 2017).

The goal of this paper is to understand the sources of cross-country variations in agricultural TFP and its growth rates by focusing on two key factors - imported intermediate inputs and weather shocks. These two variables are critical in explaining agricultural productivity. Trade in intermediate inputs covers 64 percent of world trade in 2014 according to the World InputOutput Table (Timmer et al., 2015 and Timmer et al., 2016) and a number of studies document economic benefits from expanding global value chains. ${ }^{2}$ Guided by these, we aim to understand its implications in agricultural sectors. Moreover, climate change-related weather variations are an important ongoing issue (e.g., IMF, 2017) and agricultural productivity may suffer increasingly from a climate change-related deterioration in weather conditions. Therefore, it is important to understand their effects on agricultural productivity.

Using data from 162 countries during the period 1991-2015, we show that the two factors are independently important for countries' agricultural sectors. Imported intermediate inputs boost productivity because they tend to be higher quality while being less expensive than domestic equivalents. Furthermore, we show that weather shocks play a role because higher temperatures and rainfall shortages reduce agricultural TFP in LICs.

These findings are new to the literature because we focus on their effects on agricultural TFP and none of the previous studies has investigated the impacts of these variables on agricultural TFP using a panel dataset with a large cross-section of countries. However, our results may not be surprising because previous work finds comparable estimates in different contexts.

One of the most interesting results comes from interactions between the two key factors we focus. Within LICs where we find significant effects of weather shocks, stronger weather effects come from countries employing less imported inputs. Higher temperatures and rainfall shortages do not seem to have significant effects on countries employing greater imported inputs. These results imply that using imported intermediate inputs reduces negative effects of weather shocks.

There are three main reasons to believe imported inputs have such effects. First, imported inputs tend to be higher quality and embed better technologies. As a result, these work to reduce producers' sensitively to weather shocks. Second, a greater share of imported inputs to total

\footnotetext{
${ }^{2}$ For example, expanding global value chains induce countries in specializing in tasks in which they have comparative advantage (e.g., Timmer et al., 2014), leading to gains from specialization. Furthermore, new imported inputs raise firm productivity (e.g., Amiti and Konings, 2007) and help create new domestic varieties (e.g., Goldberg et al., 2010).
} 
intermediate inputs makes the overall quality of inputs less sensitive to local weather shocks, because local climate has no effects on the quality of imported inputs. ${ }^{3}$ Third, local final good producers are intermediate good suppliers because there are sectoral linkages. Local final good producers' productivity gains through imported inputs have positive effects on domestic intermediate goods. This contributes to make domestic input quality less climate sensitive, which in turn leads to more climate-robust agricultural sectors.

This paper contributes to two different strands of literature. First, it is related with the literature on productivity gains from imported intermediate inputs. It finds that imported inputs increase firms' productivity in manufacturing industries because those inputs tend to be higher quality and less expensive (e.g., Amiti and Konings, 2007; Topalova and Khandelwal, 2011). ${ }^{4}$ To the best of our knowledge, all prior studies focuse on manufacturing industries, with a few exceptions, such as Chevassus-Lozza et al. (2013) focusing on the French food agriculture industry, and Olper et al. (2017) analyzing the data from the French and Italian food processing industry. ${ }^{5}$ The current paper is the first to shed light on agricultural industry in general in the context of gains from imported inputs. ${ }^{6}$

Second, this paper contributes to the literature on the impacts of weather shocks on agricultural sectors. The previous work on this issue focuses on certain areas of the world (e.g., Deschenes and Greenstone, 2007, for the U.S., Aschenfelter and Storchmann, 2006, for Germany, and Wang et al., 2009, for China) and they are silent about cross-country differences in the effect of weather shocks. In contrast, by employing a large panel dataset we find that countries' income levels play a role in explaining countries' sensitivities to weather shocks. In particular, we find that only LICs are negatively impacted by higher temperatures and rainfall shortages. In this regard, this paper is attuned to recent studies finding significant effects of weather shocks in lower income countries (e.g., Dell et al., 2012, for GDP growth rate; and Cattaneo and Peri, 2016, for emigration from countries).

Our contribution is three-fold. First, our results imply that an increase in imported intermediate inputs, instrumented by tariff cuts and inward FDI, has a positive effect on agricultural TFP. A one percentage point increase in the share of imported inputs to total value of intermediate goods raises TFP by 3-4 percent. This result is robust to wide range of specifications and samples. This

\footnotetext{
${ }^{3}$ For example, Caselli et al. (2015) show that diversified sources of imports and export destinations reduce a country's income volatility.

${ }^{4}$ Amiti and Konings (2007) analyze the firm-level data from Indonesia. Topalova and Khandelwal (2011) work with the data from India. See also Halpern et al. (2015) for evidence from Hungary and Kasahara and Rodrigue (2008) for evidence from Chile.

${ }^{5}$ The former study, Chevassus-Lozza et al. (2013), uses data from the French agricultural goods industry and finds that input tariff cuts led to the exit of the least productive firms and increased export sales of more productive firms. Olper et al. (2017) shows that a reduction of input tariffs increased French and Italian food processing firms' productivity.

${ }^{6}$ While the prior empirical studies employ firm-level microdata for a given country, this paper uses country-level macro data. We use a macro panel dataset instead of micro data because it is difficult to obtain micro data from the agricultural sector, particularly in lower income countries. In these countries, agricultural industries tend to rely on family-owned farms or individual workers instead of firms.
} 
study is the first to show the positive effect of imported inputs on agricultural TFP using a large panel dataset.

Second, by exploiting plausibly exogenous year-to-year fluctuations in temperatures and rainfalls, we find that for LICs, higher temperatures have a negative impact on TFP and greater rainfalls have a positive one. This is consistent with prior articles arguing that agricultural production in developing countries are more sensitively affected by weather shocks because these countries tend to have lower capital-to-labor ratios and their technologies are more climate sensitive (Mendelsohn et al., 2001, 2006). We are the first to show this using a panel dataset on agricultural TFP, which makes it possible to overcome bias coming from time-invariant omitted variables as in recent studies such as Dell et al. (2012) and Cattaneo and Peri (2016).

Third, we go beyond the existing literature by finding interactions between imported inputs and climate effects in explaining agricultural TFP. While previous studies have found that incomelevels explain countries' sensitivity to climate, we are the first to document that prevalence of imported inputs reduces countries' vulnerability to weather shocks.

The rest of the paper is organized as follows. The next section conducts a growth accounting exercise and estimates agricultural TFP. Section III presents summary of data and discusses our motivations. Section VI empirical assesses the effect of imported inputs and weather shocks on agricultural TFP. It also considers interactions between these two variables in explaining the impact of weather shocks. Section V conducts counterfactual exercises to understand economic magnitudes of the estimated impacts. Section VI concludes.

\section{Agricultural TFP}

\section{A. The Method Estimating Agricultural TFP}

We start from estimating agricultural TFP. Agricultural value-added is decomposed into TFP and of three inputs: capital stock, labor force, and land area in the agricultural industry. We first discuss the methodology, followed by a description of data sources, and then results are presented.

As in Herrendorf et al. (2015) and many others, ${ }^{7}$ country $i$ 's agricultural production function in year $t$ is described by a Cobb-Douglas production function subject to constant returns to scale $(\mathrm{CRS}):^{8}$

$$
Y_{i t}=A_{i t}\left(K_{i t}\right)^{\alpha_{i t}^{K}}\left(L_{i t}\right)^{\alpha_{i t}^{L}}\left(T_{i t}\right)^{\alpha_{i t}^{T}} \text { with } \alpha_{i t}^{K}+\alpha_{i t}^{L}+\alpha_{i t}^{T}=1
$$

\footnotetext{
${ }^{7}$ Herrendorf et al. (2015) examine structural transformation in the postwar United States by estimating CobbDouglas production functions for the agriculture industry. Other studies assuming a Cobb-Douglas production includes Macours and Swinnen (2000), Gollin and Rogerson (2014), and Craig et al. (1997).

${ }^{8}$ Previous articles employ various factors as inputs in addition to capital stock, employment, and land area. For example, Coelli and Rao (2005) include fertilizers and livestock as inputs in the agricultural production function. However, we do not include these as inputs because the data on fertilizers and livestock are not available for many countries, and we would need to drop many countries from the sample if we were to include these. In Section IV, we include fertilizers as a determinant of TFP following Craig et al. (1997).
} 
where $Y_{i t}, A_{i t}, K_{i t}, L_{i t}$ and $T_{i t}$ are value-added, TFP, capital stock, employment, and land area in the agricultural industry, respectively. $\alpha_{i t}^{K}, \alpha_{i t}^{L}$ and $\alpha_{i t}^{T}$ are the income shares of capital stock, labor, and land, respectively. Note that these income shares have country and year subscripts, meaning that these are different across countries and across time.

Data on agricultural value-added, agricultural capital stock, and agricultural land area are taken from FAO (2018) and data on agricultural employment come from the World Bank (2018a). We take the income share and the labor share data from the EORA database (Lenzen et al., 2012, 2013). It provides the data on payments to capital (consumption of fixed capital), payments to labor (compensation of labor), and value-added. ${ }^{9}$ We compute the capital share as $\alpha_{i t}^{K}=$

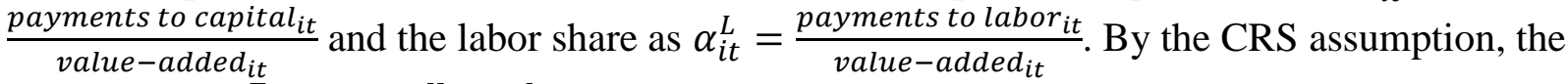
land share is $\alpha_{i t}^{T}=1-\alpha_{i t}^{K}-\alpha_{i t}^{L}$.

TFP is then obtained as a residual: $A_{i, t}=Y_{i, t} /\left[\left(K_{i t}\right)^{\alpha_{i t}^{K}}\left(L_{i t}\right)^{\alpha_{i t}^{L}}\left(T_{i t}\right)^{\alpha_{i t}^{T}}\right] .{ }^{10}$ Annualized long-run growth rates of value added of country $i$ from 1991 to $2015, g_{i, 1991-2015}^{V A}=100 \times\left[\ln \left(V A_{i, 2015}\right)-\right.$ $\left.\ln \left(V A_{i, 1991}\right)\right] / 24$, are decomposed into four components:

TFP: $g_{i, 1991-2015}^{T F P}=100 \times\left[\ln \left(A_{i, 2015}\right)-\ln \left(A_{i, 1991}\right)\right] / 24$,

Capital stock: $g_{i, 1991-2015}^{K}=100 \times \alpha_{i t}^{K}\left[\ln \left(K_{i, 2015}\right)-\ln \left(K_{i, 1991}\right)\right] / 24$,

Employment: $g_{i, 1991-2015}^{L}=100 \times \alpha_{i t}^{L}\left[\ln \left(L_{i, 2015}\right)-\ln \left(L_{i, 1991}\right)\right] / 24$,

Land area: $g_{i, 1991-2015}^{T}=100 \times \alpha_{i t}^{T}\left[\ln \left(T_{i, 2015}\right)-\ln \left(T_{i, 1991}\right)\right] / 24$.

This decomposition exercise is conducted for each of the countries available.

Our sample includes 162 countries in the world. However, not all countries have complete data from 1991 to 2015 . The growth accounting exercise focuses on countries where complete data from 1991 to 2015 are available. As a result, the sample size is restricted to 135 countries - 25 LICs, 35 lower-middle-income countries, 34 upper-middle-income countries, and 41 highincome countries.

We also provide alternative TFP estimate based on factor shares obtained by estimating a loglinearized Cobb-Douglas production function, which we call $\mathrm{TFP}_{b}$. The productivity measure $\mathrm{TFP}_{b}$ is based on a strong assumption that all countries have the same factor shares. However, this measure of TFP covers a slightly greater number of countries - 27 LICs, 37 lower-middle income countries, 38 upper-middle income countries, 42 high-income countries, totaling 144 countries. $\mathrm{TFP}_{b}$ estimates are used for robustness checks of regression analyses. ${ }^{11}$

\footnotetext{
${ }^{9}$ Consumption of fixed capital includes all tangible and intangible assets owned by producers and excludes nonproduced assets such as land, mineral, coal, oil, or natural gas. Therefore, we employ this measure to find the capital share.

${ }^{10}$ See Appendix B for more details on data. See Appendix D.1 for calculated factor shares.

${ }^{11}$ See Appendix D.2 for more details on the productivity measure $\mathrm{TFP}_{b}$.
} 


\section{B. Results from Growth Accounting}

Table 1 presents results from the growth accounting exercise for four groups of countries. It shows simple averages of the growth rates of agricultural value-added and those of four decomposed components. TFP grew the most in lower-middle income countries - the annual average growth rate is 2.3 percent over the period 1991-2015. Upper-middle income countries $(2.16 \%)$, high-income countries (1.93\%), and LICs (1.87\%) follow.

Agricultural value-added growth rate in LICs, 3.32 percent, is higher than that from richer countries. However, relatively higher input growth rate led to a small contribution of TFP. Highincome countries have a lower value-added growth rate than other groups of countries, 1.08 percent. However, the TFP growth rate is estimated to be fairly high due to the fact that there is a decrease in inputs such as labor $(-1.22 \%)$ and land $(-0.02 \%)$.

Table 1: Growth Accounting Results, Countries Grouped by Income Level, 1991-2015

\begin{tabular}{lrrrrr}
\hline & \multirow{2}{*}{$\begin{array}{c}\text { Value- } \\
\text { added }\end{array}$} & \multicolumn{4}{c}{ Capital } \\
& & TFP & stock & Labor & Land \\
\hline Low-income countries & 3.32 & 1.87 & 0.86 & 0.69 & 0.30 \\
Lower-middle income countries & 3.42 & 2.29 & 1.43 & -0.03 & 0.26 \\
Upper-middle income countries & 3.01 & 2.16 & 1.49 & -1.27 & 0.42 \\
High-income countries & 1.08 & 1.93 & 0.39 & -1.22 & -0.02 \\
\hline
\end{tabular}

Notes: The table shows the decomposition of the annual average growth in agricultural value-added over 24 years, from 1991 to 2015. The growth accounting exercise is conducted at the country-level first and then the simple average of each country's growth rates are found. Countries' income levels are based on the World Bank's classification. See the main text for data sources.

Figure 1 summarizes results from each of LICs over the 24-year period 1991-2015.12 Out of the 27 countries, Mali, Chad, and Liberia have the highest value-added growth rates: annual average growth rates of 7.7 percent, 6.8 percent, and 6.2 percent, respectively. TFP contributes the most in Mali and Chad: 3.5 percent and 3.6 percent, respectively. On the other hand, the growth in the capital stock explains the largest part of the agricultural value-added growth in Liberia, 3.5 percent. Among the LICs, Central African Republic, Burundi, and Haiti have the smallest valueadded growth rate over the period: 0 percent, -0.14 percent, and -0.27 percent, respectively. All of these three countries have non-positive TFP growth rates and negative capital stock growth rates.

\footnotetext{
${ }^{12}$ We follow the World Bank's classification for income-level of countries. See Appendix C for results from individual countries from other groups of countries.
} 
Figure 1: Growth Accounting Results, LICs, 1991-2015

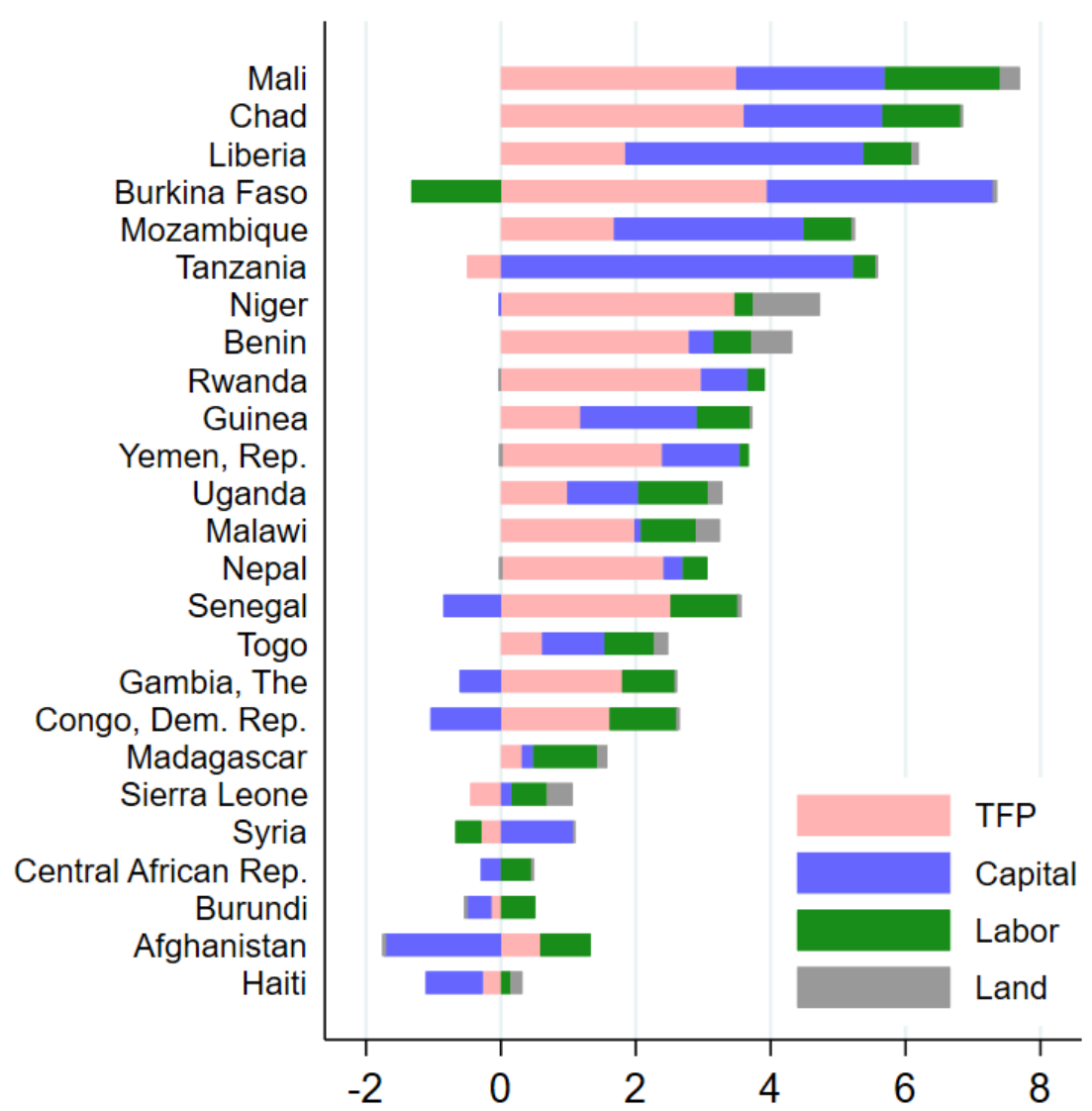

Notes: The figure shows annualized average growth rates of each component over 24 years, 1991-2015. See the main text for data sources. See Appendix $\mathrm{C}$ for a table for showing the growth rates of value-added and each component.

We are also interested in agricultural productivity levels and their gaps across countries. Figure 2 shows the average agricultural TFP for the four groups of countries. Panel A presents average TFP levels and shows that TFP levels have been increasing in all groups of countries over the period 1991-2015. Panel B displays the TFP levels normalized so as to make the TFP levels from 1991 to be one. It shows that among these four groups of countries, TFP levels increased almost at the same rate for all of the four groups of counties. We seek to disentangle the sources of this productivity gap. 
Figure 2: Agricultural TFP Levels by Income-Level of Countries, 1991-2015
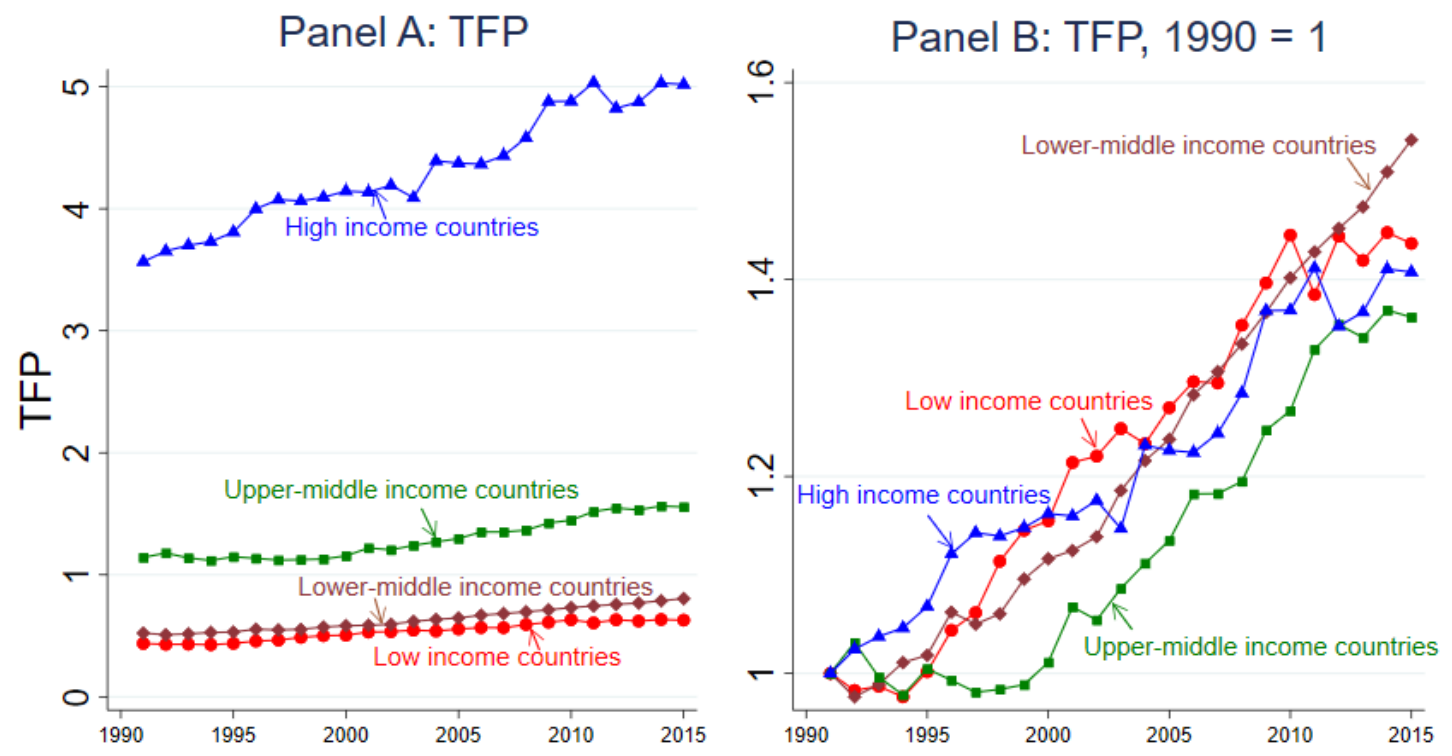

Notes: The figure shows the simple average of agricultural TFP levels for the four groups of countries. Countries' income levels are based on the World Bank's classification. See the main text for the data sources.

\section{STYLIZED FACTS ON IMPORTED INPUTS, AND WEATHER SHOCKS}

We focus on two variables, imported inputs and weather shocks, to explain cross-country variations in agricultural TFP. This section presents empirical observations on these variables by showing their time-series variations by country income group.

Figure 3 shows the share of imported inputs to total purchase of intermediate goods in the agricultural sector. It indicates that high-income countries consistently have a higher share of imported inputs among the four groups of countries after 1995, and LICs always have the lowest share except for the year 2000. In terms of time-series variation, there is a slight declining trend of the share of imported inputs in the 1990s and it is increasing since early 2000s. There are sharp declines in the share of imported inputs during 2008-2010 due to the 2008-09 global financial crisis.

We display average temperatures and rainfalls across the four groups of countries in Figure 4. Panel A shows that lower income countries tend to have higher average temperatures. Average temperatures are rising over the period 1991-2015. Panel B indicates that middle-income countries have greater rainfalls on average. LICs and high-income countries have similar levels of rainfalls. 
Figure 3: The Share of Imported Inputs by Income-Level of Countries, 1990-2015

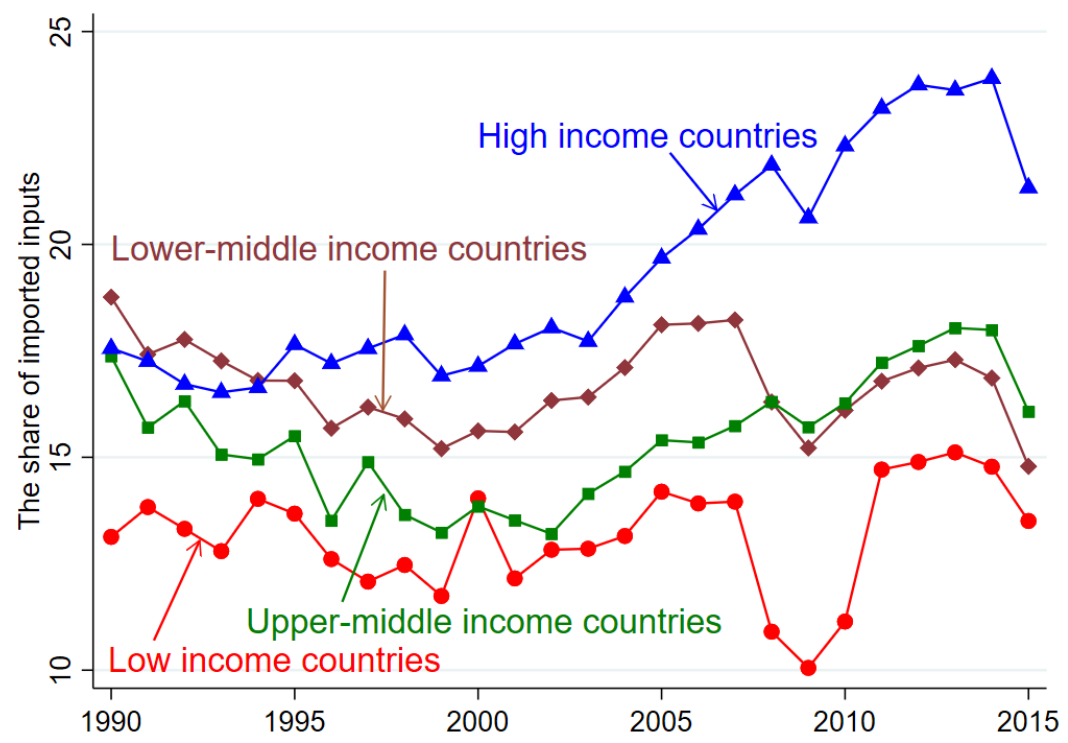

Notes: The figure shows simple averages of the share of imported inputs to total inputs for the four groups of countries. The authors' calculation based on the data from the EORA (Lenzen et al., 2012, 2013).

Figure 4: Temperatures and Rainfalls by Income-Level of Countries, 1990-2015
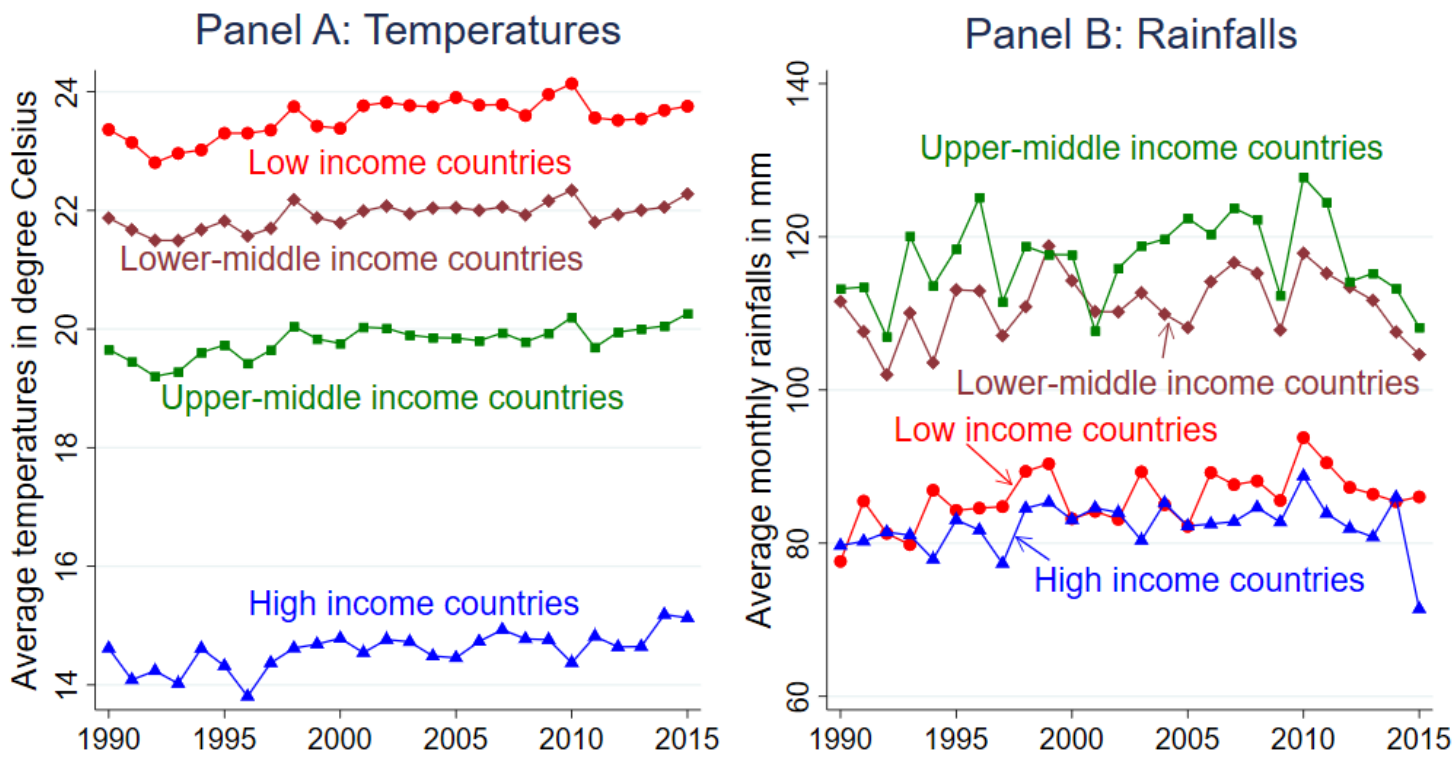

Notes: The figure shows the simple average of yearly average temperatures in degree Celsius and average monthly rainfalls in millimeters $(\mathrm{mm})$ for the four groups of countries. The authors' calculation based on the data from World Bank (2018b). 
Figure 5: Average Temperatures and Rainfalls in 2015 and their Long-Run Changes since 1990

\section{Part I: Distribution of Average Temperatures and Long-Run Changes}
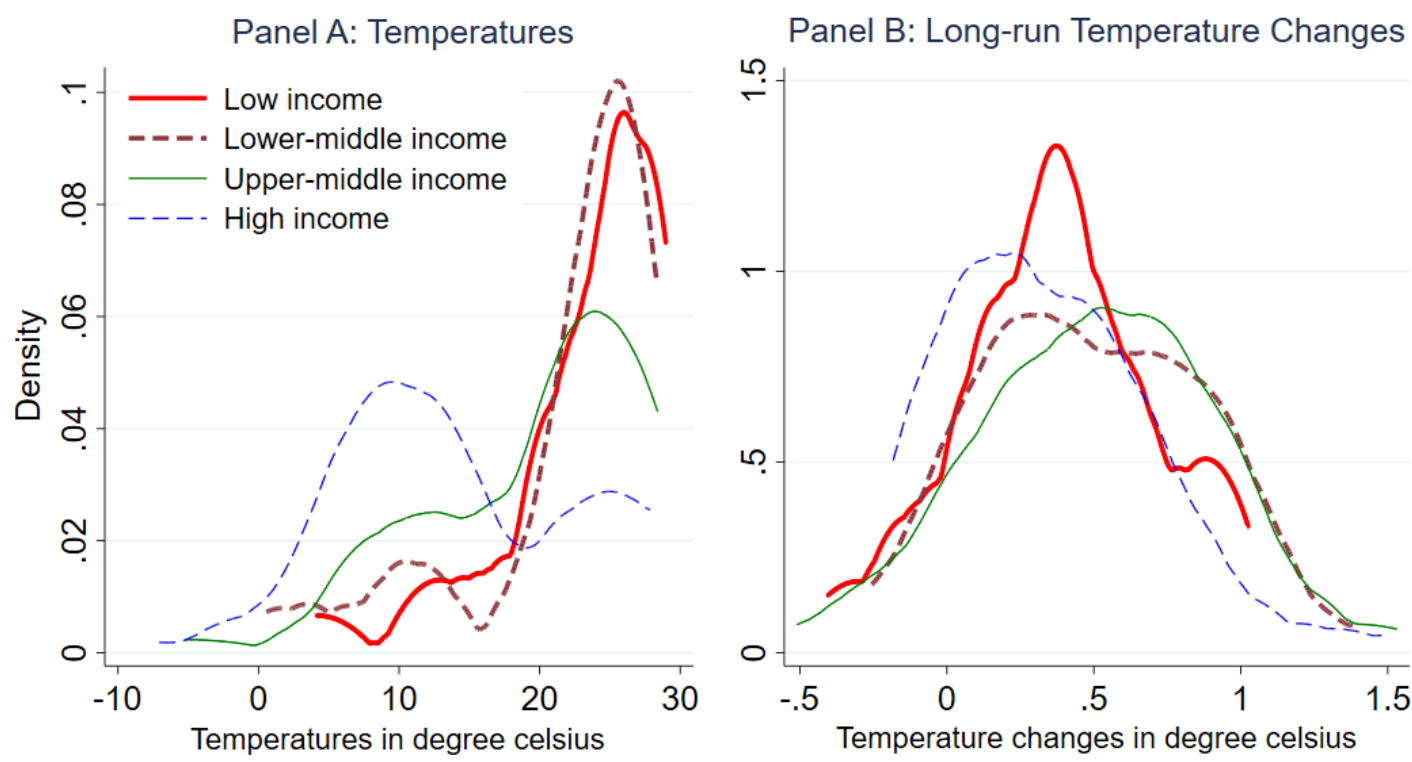

Part II: Distribution of Average Rainfalls and Long-Run Changes
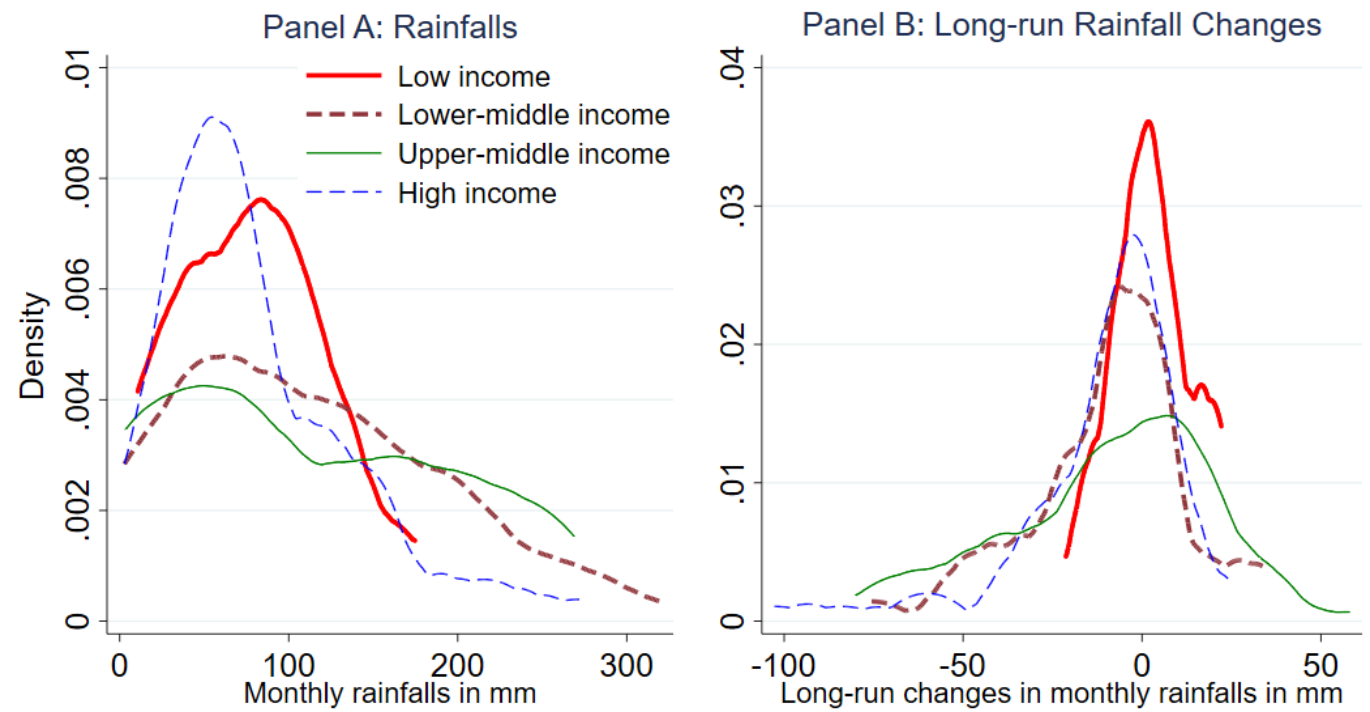

Notes: The authors' calculation based on the data from World Bank (2018b). The figures show kernel density estimates of average temperatures in degree Celsius and average monthly rainfalls in millimeters in Panel A of Part I and Part II, respectively. Long-run changes in temperatures and rainfalls between 1990 and 2015 are shown in Panel B of Part I and Part II, respectively. Countries' income levels are based on the World Bank's classification.

Figure 5 shows kernel density estimates of average of temperatures and rainfalls using the data from 2015. Panel A of Part I indicates that average temperatures are right-skewered in LICs and middle-income countries. The modes of the distributions are above 25 degrees Celsius. On the 
other hand, average temperatures for high-income countries is almost normally distributed and the mode is about 10 degrees Celsius. Panel B of Part I shows the long-run changes in average temperatures between 1990 and 2015. Strikingly, most countries experienced a rise in temperatures. The modes are above zero for all groups of countries. Panel A of Part II presents kernel density estimates of average monthly rainfalls and their long-run changes during 19902015 are presented in Panel B. Long-run changes in rainfalls are almost symmetrically distributed with mean zero.

\section{REgRESSION ANALYSIS}

\section{A. Imported Inputs and Agricultural TFP Level}

This section examines the role of imported inputs in determining agricultural TFP. By closely following prior studies investigating determinants of TFP, we estimate the following regression model: ${ }^{13} 14$

$$
\ln \left(\text { TFP }_{i, t}\right)=\beta_{i}+\beta_{1} \text { ImInputs }_{i, t}+\mathbb{X}_{i, t} \boldsymbol{\beta}_{2}+e_{i, t},
$$

where $\ln \left(T F P_{i, t}\right)$ denotes natural $\log$ of TFP in country $i$ in year $t ; \beta_{i}$ indicates country fixed effects; ImInputs $s_{i, t}=100 \times$ Imported Inputs $_{i, t} /$ Total Inputs $_{i, t}$ is the value of imported intermediate inputs divided by the value of total intermediate inputs times $100 ; \mathbb{X}_{i, t}$ is a vector of control variables including the consumption of fertilizers and pesticides, the capital-to-labor ratio, the production taxes-to-value added ratio, the production subsidies-to-value added ratio, the political instability index, the expenditure share on research and development, and temperatures and rainfalls ${ }^{15} ; e_{i, t}$ is an error term; $\beta_{1}$ and $\boldsymbol{\beta}_{2}$ are a scalar parameter and a vector of parameters to be estimated, respectively.

OLS estimates would lead to a bias because there is reverse causality from the level of TFP to countries' decisions to import. For example, productive countries may be more likely to import inputs from abroad because they have a greater incentive to remain competitive and increase

\footnotetext{
${ }^{13}$ Previous studies estimating the impact of imported inputs on firm productivity employs either natural log of TFP (Olper et al el., 2017; Amiti and Konings, 2007) or TFP index (Topalova and Khandelwal, 2011) or natural log of firm sales (Halpern et al., 2015). All of these studies use firm-level data. Previous studies investigating determinants of TFP using country-level macro data include Craig et al. (1997) and Alene (2010). Craig et al. (1997) employ natural log of labor productivity as the dependent variable. Alene (2010) uses natural log of TFP as the dependent variable. See Appendix E for more details regarding the empirical specification.

${ }^{14}$ To address the potential existence of a trend in the growth rate of TFP, a Hariss-Tzavalis unit-root test for $\ln (\mathrm{TFP})$ was run for a strongly balanced panel dataset of 135 countries over 24 years (1991-2015). The test statistic obtained is 0.8429 with $p$-value of 0.000 . Therefore, the null hypothesis that the panel variable contain unit roots is rejected at the 1 percent level. Furthermore, since we include country fixed effects, all variables are transformed to demeaned variables. As a result, we estimate the effect of changes in the share of imported inputs on changes in $\ln (\mathrm{TFP})$, which are percentage deviations from their country means.

${ }^{15}$ The unit of the variable for fertilizers and pesticides are tons per hectare. We normalize each of these variables, by calculating deviation from its mean and by divided by its standard deviation. Then the sum of these two variables are defined as the variable "Fertilizers and pesticides". The political instability index takes a discrete value between one and seven. A greater value implies that the observation is more politically unstable. It represents political factors relating with civil liberty. See Freedom House (2018) for more details. See Appendix B for summary statistics.
} 
their global market share. Alternatively, less productive countries may be less likely to import because they often have a set of stringent industrial policy design setups biased towards domestically produced inputs. If the former story were true, $\beta_{1}$ would have an upward bias; on the other hand, $\beta_{1}$ would have a downward bias if the latter story were true.

In order to overcome this potential endogeneity, we employ tariffs applied by importing countries and inward FDI (as a share of agricultural value-added) as instruments. These variables are valid instruments because they satisfy the relevancy condition and the exclusion restriction. First, a decline in tariffs increases imported inputs but it does not affect agricultural TFP other than through changes in the value of imported inputs. Second, an increase in inward FDI to the agricultural sector increases imported inputs because these foreign-owned agricultural entities are more likely to use imports from abroad. An increase in inward FDI may increase agricultural TFP directly if there are some spillovers from foreign-owned entities. However, econometric tests suggest that our instruments satisfy the exclusion restriction.

The data come from various sources. Section II laid out the underlying sources of data used to calculate TFP. The data on imported inputs come from the EORA Input-Output tables (Lenzen et al. 2012; Lenzen et al., 2013). The share of imported intermediate goods to the total intermediate good used is computed for the agricultural sector for all EORA 189 countries and then the data on imported inputs are matched with our agricultural productivity dataset. The data on fertilizer consumption per area and R\&D expenditures comes from the WDI. Pesticide consumptions per area are from FAO. We obtain the political instability index from the Freedon House. The data on the capital-to-labor ratio, production taxes, and production subsidies are from the EORA. Temperature and rainfall are taken from the World Bank Climate Change Knowledge Portal (World Bank, 2018b). See Appendix B for more details.

Table 2 reports regression results. The first two columns employ OLS - column (1) regresses log of TFP on imported inputs only and column (2) introduces other control variables. The results show that the imported inputs-to-total inputs ratio does not have a significant effect on TFP levels. These insignificant coefficients are presumably because there are endogeneity issues, leading to bias in both ways - negative and positive. As a result, we obtain zero point estimates. ${ }^{16}$

The last four columns in Table 2 show results from 2SLS. Column (3) employs the imported inputs-to-total inputs ratio as the only explanatory variables and shows that a one percentage point increase in the share of imported inputs raises TFP by 8.9 percent. Columns (4)-(6) introduce additional control variables. Column (4) includes the same set of regressors as for column (2). All of the additionally introduced variables have expected signs. ${ }^{17}$ After controlling for these, the point estimate for the effect of imported inputs becomes 4.4. Column (4) is our preferred specification because the first-stage $F$-statistic is great enough and the Sargan test suggests that the exclusion restriction is satisfied.

\footnotetext{
${ }^{16}$ Indeed, results from the Hausman tests reported in IV columns, (3)-(6), show that the null hypothesis that there is no endogeneity is rejected at the 1 percent level.

${ }^{17}$ We expect positive signs from fertilizers and pesticides, the capital-labor ratio, and subsidies because these work to increase agricultural production, therefore TFP. On the other hand, we expect negative signs from taxes and the political instability index because these variables are anticipated to reduce agricultural production and TFP.
} 
Table 2: Determinants of TFP, Baseline Results Dependent Variable $=100 \times \ln ($ TFP)

\begin{tabular}{|c|c|c|c|c|c|c|}
\hline & \multicolumn{2}{|c|}{ OLS } & \multicolumn{4}{|c|}{2 SLS } \\
\hline & $(1)$ & (2) & (3) & (4) & $(5)$ & (6) \\
\hline \multirow[t]{2}{*}{ Imported inputs/Total inputs $\times 100$} & 0.101 & -0.048 & $8.863 * * *$ & $4.399 * * *$ & $4.023 * *$ & $3.995 * * *$ \\
\hline & $(0.246)$ & $(0.371)$ & $(1.093)$ & $(1.290)$ & $(1.677)$ & $(1.114)$ \\
\hline \multicolumn{7}{|l|}{ Controls } \\
\hline \multirow[t]{2}{*}{ Fertilizer \& pesticides } & & $0.465^{*}$ & & $4.122 * * *$ & $4.590 * * *$ & $3.924 * * *$ \\
\hline & & $(0.274)$ & & $(1.304)$ & $(1.344)$ & $(1.281)$ \\
\hline \multirow[t]{2}{*}{ Capital-labor ratio } & & -0.020 & & $0.344 * * *$ & $0.426 * * *$ & $0.368 * * *$ \\
\hline & & $(0.165)$ & & $(0.096)$ & $(0.124)$ & $(0.089)$ \\
\hline \multirow[t]{2}{*}{ Taxes } & & $-0.420 * * *$ & & -1.606 & -1.433 & -1.717 \\
\hline & & $(0.038)$ & & $(1.241)$ & $(1.182)$ & (1.209) \\
\hline \multirow[t]{2}{*}{ Subsidies } & & $0.003 * * *$ & & 0.475 & 0.421 & 0.600 \\
\hline & & $(0.000)$ & & $(0.593)$ & $(0.581)$ & $(0.581)$ \\
\hline \multirow[t]{2}{*}{ Political instability index } & & 1.445 & & $-7.596 * * *$ & -4.011 & $-5.734 * *$ \\
\hline & & $(2.821)$ & & $(2.520)$ & $(2.495)$ & $(2.569)$ \\
\hline \multirow[t]{2}{*}{ Research \& development } & & & & & 2.237 & \\
\hline & & & & & $(6.725)$ & \\
\hline \multirow[t]{2}{*}{ Temperatures } & & & & & & -1.752 \\
\hline & & & & & & $(1.738)$ \\
\hline \multirow[t]{2}{*}{ Rainfalls } & & & & & & 0.023 \\
\hline & & & & & & $(0.051)$ \\
\hline Country fixed effects & Yes & Yes & Yes & Yes & Yes & Yes \\
\hline Observations & 3,914 & 1,511 & 2,654 & 455 & 371 & 424 \\
\hline Countries & 162 & 111 & 161 & 61 & 54 & 56 \\
\hline Cragg-Donald Wald $F$-statistic & & & 44.65 & 12.90 & 8.43 & 15.73 \\
\hline Sargan statistic & & & 1.285 & 0.045 & 0.021 & 0.025 \\
\hline$p$-value of Sargan statistic & & & 0.257 & 0.831 & 0.885 & 0.874 \\
\hline Hausman statistic & & & 123.74 & 16.03 & 8.20 & 15.83 \\
\hline$p$-value of Hausman statistic & & & 0.000 & 0.000 & 0.004 & 0.000 \\
\hline
\end{tabular}

Notes: All regressions include country fixed effects. Standard errors are in parentheses. $* * *, * *$, and $*$ indicate the statistical significance at the $1 \%, 5 \%$, and $10 \%$ level, respectively. Instruments include weighted average tariffs on all products and the share of inward FDI to the agricultural sector to the agricultural value-added. See the main text for data sources. 
Table 3: Determinants of TFP, Robustness Checks

Dependent Variable $=100 \times \ln (\mathrm{TFP})$ or $100 \times \ln ($ Value-Added $)$, or $100 \times \ln \left(\mathrm{TFP}_{b}\right)$

\begin{tabular}{|c|c|c|c|c|c|c|}
\hline \multirow{3}{*}{ Dependent variable } & \multicolumn{2}{|c|}{$\begin{array}{l}\text { Baseline specification } \\
\& \text { baseline sample }\end{array}$} & $\begin{array}{c}\text { Excluding } \\
\text { high } \\
\text { income } \\
\text { countries }\end{array}$ & $\begin{array}{l}\text { Excluding } \\
\text { oil } \\
\text { producers }\end{array}$ & $\begin{array}{l}\text { Excluding } \\
\text { the period } \\
\text { of } \\
\text { commodity } \\
\text { price hikes }\end{array}$ & $\begin{array}{l}\text { Adding the } \\
\text { effective } \\
\text { exchange } \\
\text { rate as an } \\
\text { instrument }\end{array}$ \\
\hline & $\begin{array}{l}\text { Value- } \\
\text { added }\end{array}$ & $\mathrm{TFP}_{b}$ & \multicolumn{4}{|c|}{ TFP } \\
\hline & $(1)$ & (2) & (3) & (4) & (5) & (6) \\
\hline Imported inputs/Total inputs $\times 100$ & $\begin{array}{c}5.408 * * * \\
(1.334)\end{array}$ & $\begin{array}{l}3.871 * * * \\
(1.115)\end{array}$ & $\begin{array}{c}4.178 * * * \\
(1.447)\end{array}$ & $\begin{array}{c}4.258 * * * \\
(1.330)\end{array}$ & $\begin{array}{c}4.006 * * * \\
(1.526)\end{array}$ & $\begin{array}{l}4.116^{* *} \\
(1.627)\end{array}$ \\
\hline \multicolumn{7}{|l|}{ Controls } \\
\hline Fertilizer \& pesticides & $\begin{array}{c}4.587 * * * \\
(1.348)\end{array}$ & $\begin{array}{c}3.211 * * * \\
(1.127)\end{array}$ & $\begin{array}{c}3.652 * * \\
(1.693)\end{array}$ & $\begin{array}{c}3.653 * * * \\
(1.352)\end{array}$ & $\begin{array}{c}5.625 * * * \\
(2.125)\end{array}$ & $\begin{array}{c}4.396 * * \\
(2.070)\end{array}$ \\
\hline Capital-labor ratio & $\begin{array}{l}-0.012 \\
(0.099)\end{array}$ & $\begin{array}{l}-0.026 \\
(0.083)\end{array}$ & $\begin{array}{c}-1.819 * * * \\
(0.693)\end{array}$ & $\begin{array}{c}0.292 * * * \\
(0.096)\end{array}$ & $\begin{array}{c}0.534 * * * \\
(0.154)\end{array}$ & $\begin{array}{c}0.266 * * \\
(0.105)\end{array}$ \\
\hline Taxes & $\begin{array}{l}-1.824 \\
(1.283)\end{array}$ & $\begin{array}{l}-1.204 \\
(1.073)\end{array}$ & $\begin{array}{l}-1.189 \\
(1.325)\end{array}$ & $\begin{array}{l}-1.565 \\
(1.267)\end{array}$ & $\begin{array}{l}-8.877 \\
(8.146)\end{array}$ & $\begin{array}{l}-14.75^{*} \\
(8.195)\end{array}$ \\
\hline Subsidies & $\begin{array}{c}0.388 \\
(0.613)\end{array}$ & $\begin{array}{l}-0.244 \\
(0.513)\end{array}$ & $\begin{array}{l}-1.064 \\
(1.576)\end{array}$ & $\begin{array}{c}0.777 \\
(0.659)\end{array}$ & $\begin{array}{c}0.198 \\
(0.738)\end{array}$ & $\begin{array}{c}2.18 \\
(1.335)\end{array}$ \\
\hline Political instability index & $\begin{array}{c}-6.801 * * * \\
(2.605)\end{array}$ & $\begin{array}{c}-4.538 * * \\
(2.178)\end{array}$ & $\begin{array}{l}-7.026^{*} \\
(3.874)\end{array}$ & $\begin{array}{c}-9.151 * * * \\
(2.886)\end{array}$ & $\begin{array}{l}-6.284 * \\
(3.474)\end{array}$ & $\begin{array}{c}-8.046 * * \\
(3.733)\end{array}$ \\
\hline Country fixed effects & Yes & Yes & Yes & Yes & Yes & Yes \\
\hline Observations & 455 & 455 & 236 & 385 & 246 & 181 \\
\hline Countries & 61 & 61 & 35 & 52 & 55 & 50 \\
\hline Cragg-Donald Wald $F$-statistic & 7.45 & 11.40 & 7.78 & 5.95 & 12.90 & 12.90 \\
\hline Sargan statistic & 0.073 & 0.009 & 0.008 & 3.997 & 0.142 & 0.007 \\
\hline$p$-value of Sargan statistic & 0.787 & 0.924 & 0.930 & 0.136 & 0.707 & 0.936 \\
\hline Hausman statistic & 17.65 & 15.07 & 9.72 & 6.19 & 29.19 & 14.82 \\
\hline$p$-value of Hausman statistic & 0.000 & 0.000 & 0.002 & 0.013 & 0.000 & 0.000 \\
\hline
\end{tabular}

Notes: The first two columns use the baseline specification presented in column (4) of Table 2. The definition of high-income countries follows the World Bank. Oil producers are countries where their oil rents as a share of GDP is greater than the $90^{\text {th }}$ percentile of the sample in 1990 (16 percent). The period of commodity price hikes are defined as years when the food price index in December of that year is greater than 12 percent of the price index in December in the previous year. The excluded years as the period of commodity price hikes are 1991, 1994, 2002, 2005, 2006, 2009, and 2010. Instruments include weighted average tariffs on all products and the share of inward FDI to the agricultural sector to the agricultural value-added. In addition to these instruments, the real effective exchange rate is added as an instrument in column (6). All regressions include country fixed effects. Standard errors are in parentheses. $* * *, * *$, and $*$ indicate the statistical significance at the $1 \%, 5 \%$, and $10 \%$ level, respectively. See the main text for data sources.

Column (5) adds the expenditure on R\&D. This is potentially an important variable in explaining agricultural TFP. However, this variable includes many missing observations, which reduces our sample size from 455 to 371 . Moreover, the first-stage $F$-statistic becomes smaller. Column (6) introduces climate variables - the level of average temperature in degree Celsius and the level of average monthly rainfall - in order to control for climatic conditions. Temperature and rainfall 
are expected to have negative and positive signs, respectively, as document in the previous literature (e.g., Barrios et al., 2010; Dell et al., 2012). The result shows that we have expected signs but these are not statistically significant. ${ }^{18}$ Overall, the results suggest that a one percentage point increase in the share of imported inputs raises agricultural TFP by about 4 percent.

Table 3 conducts several robustness checks to show that our baseline results are robust. Columns (1) and (2) employ natural $\log$ of agricultural value-added and natural $\log$ of $\operatorname{TFP}_{b}$ as the dependent variables, respectively, using our baseline specification, column (4) of Table 2. ${ }^{19} \mathrm{We}$ use these dependent variables in order to show that our baseline results do not come from particular assumptions we make to estimate TFP. Indeed, results remain qualitatively the same. A one percentage point increase in the share of imported inputs raises value-added by 5.4 percent and $\mathrm{TFP}_{b}$ by 3.9 percent.

Column (3) excludes observations from high-income countries because one may argue that these countries are different from other lower income countries in terms of the way they produce agricultural goods. However, excluding these countries does not change our results much. Column (4) drops oil producers. ${ }^{20}$ However, again, the results are similar to those reported in Table 2. We drop periods of commodity price increases in column (5) because an exceptional increase in commodity prices may increase the value of agricultural output and therefore valueadded and TFP. However, the result in column (5) is similar to those in other columns.

Lastly, one may claim that the real effective exchange rate can also be used as instruments because changes in real exchange rates alter the relative prices of imported inputs to domestic inputs, affecting countries' decitions to import intermediate inputs. Therefore, column (6) adds the real effective exchange rate as an additional instrument. However, results do not change qualitatively.

We compare our results with previous empirical findings. Halpern et al. (2015), Topalova and Khaldelwal (2011), and Amiti and Konings (2007) find that a 10 percent decrease in input tariffs raises TFP by 1.2-1.5 percent, 4.8 percent, and 12 percent, respectively. ${ }^{21}$ In order to compare

\footnotetext{
${ }^{18}$ One reason why we have insignificant climate effects is that we do not allow different responses to weather shocks across countries, which will be addressed in the next section. These weather variables are added in the regression just to control for climatic conditions.

${ }^{19}$ As noted earlier, $\mathrm{TFP}_{b}$ denotes another TFP estimates based on equal values of the labor share, the capital share, and the land share across countries. See Appendix D.2 for details.

${ }^{20}$ Our measure of TFP is based on the data from the agricultural sector, which does not include mining and oils. Still, we concerned about the possibility that natural resource booms affect productivity of other industries, so-called a "Dutch disease" or a "Natural resource curse".

${ }^{21}$ Topalova and Khaldelwal (2011) show, using data from Indian manufacturing firms, that a 10-percentage point decrease in input tariffs increases TFP by 4.8 percent. Amiti and Konings (2007) show, using the data from Indonesian manufacturing firms, that a 10-percentage point decrease in input tariffs increase productivity by 12 percent. Halpern et al. (2015) show that, using the data from Hungarian manufacturing firms, a tariff cut from 40 percent to 30 percent increases productivity by 1.2 percent to 1.5 percent. Chevassus-Lozza et al. (2013) estimate the impact of lowering input tariffs on firms' decision to export using the firm-level data from the French agricultural
} 
with these figures, we combine our first-stage and second-stage results. The first-stage regressions indicate that a 10 percentage point decline in tariffs increases the share of imported inputs to total inputs, $\frac{\text { Imported inputs }}{\text { Total inputs }}$, by 3 percentage points. The second-stage results show that a 1 percentage point increase in $\frac{\text { Imported inputs }}{\text { Total inputs }}$ raises TFP by 4 percent. Combining these implies that a 10 percentage point decrease in tariffs is associated with a 12 percent increase in the level of TFP. This number is almost the same as Amiti and Konings (2007)'s result.

\section{B. Weather Shocks and Agricultural TFP Growth}

The second key determinant of agricultural TFP is weather shocks, i.e., temperatures and rainfalls. Agricultural sectors are known to be more sensitively affected by weather shocks and climate change (Mendelsohn et al., 2001; and Mendelsohn et al., 2006). Moreover, previous studies find that countries' responses to weather shocks vary substantially depending upon income levels of countries (e.g., Dell et al., 2012; Cattaneo and Peri, 2016). Guided by these, this section seeks to understand if there are similar cross-country differences in the impacts of weather shocks on agricultural TFP.

We closely follow the literature to setup our regression model. Previous studies investigate the impact of weather shocks on the GDP growth rate by implicitely assuming that weather shocks affect the current level of GDP by changing its growth path from the previous year (Dell et al., 2012; Hsiang and Jina, 2014; Moore and Diaz, 2015; IMF, 2017).22 We assume that a similar argument applies in the context of agricultyral TFP. Therefore, our baseline regression model is: ${ }^{23}$

$$
\begin{aligned}
& g_{i, t}^{T F P}=\gamma_{0}+\gamma_{1} d . \text { Temp }_{i, t}+\gamma_{1}^{\text {Low }}\left[\text { d.Temp } p_{i, t} D_{i}^{\text {Low }}\right]+\gamma_{1}^{\text {Middle }}\left[\text { d.Temp } p_{i, t} D_{i}^{\text {Middle }}\right]
\end{aligned}
$$

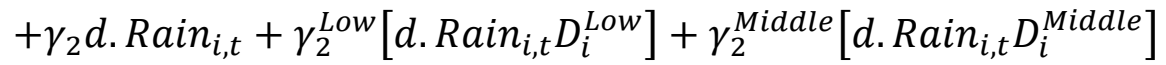

$$
\begin{aligned}
& +D_{i}^{\text {Low }} \theta_{t}+D_{i}^{\text {Middle }} \theta_{t}+\varepsilon_{i, t},
\end{aligned}
$$

where $g_{i, t}^{T F P}=100 \times\left(T F P_{i, t}-T F P_{i, t-1}\right) / T F P_{i, t-1}$ denotes the annual growth rate of TFP of country $i$ in year $t$; $d$ Temp $_{i, t}=T e m p_{i, t}-\operatorname{Temp}_{i, t-1}$ is the annual change in average temperatures in degree Celsius; $d . \operatorname{Rain}_{i, t}=\operatorname{Rain}_{i, t}-\operatorname{Rain}_{i, t-1}$ is the annual change in average

\footnotetext{
food industry. They conduct a simulation analysis based on their regression results. They find that a 10 percent decrease in input tariffs applied to all sectors increases total export sales by 1.1 percent and employment by 0.1 percent. Olper et al. (2017) find that, using firm-level data from France and Italy, a 10 percent increase in the value of imported inputs raises TFP by 2.1 percent.

${ }^{22}$ Dell et al. (2014) provide a simple theoretical background. See Appendix E for more details.

${ }^{23}$ The model controls for country fixed effects because all variables are measured in changes (or percentage change) from previous years. Following Dell et al. (2012), two-way clustering standard errors by Cameron et al. (2011) are used to find robust standard errors where these are clustered in two ways, at the country-level and at the regionlevel.
} 
monthly rainfalls in $100 \mathrm{~mm}^{24} ; D_{i}^{L o w}$ and $D_{i}^{\text {Middle }}$ are dummy variables taking unity if country $i$ is a LIC and a middle-income country, respectively; $\theta_{t}$ and $\varepsilon_{i, t}$ denote year fixed effects and an error term, respectively; $\gamma_{0}, \gamma_{1}^{\text {Low }}, \gamma_{1}^{\text {Middle }}, \gamma_{2}, \gamma_{2}^{\text {Low }}$, and $\gamma_{2}^{\text {Middle }}$ are coefficients to be estimated.

Climate variables, $d$. Temp $_{i, t}$ and $d$. Rain $_{i, t}$, are interacted with income-level dummies in order to capture heterogeneous responses to weather shocks across the three groups of countries - lowincome countries, middle-income countries, and high-income countries. With these dummies and all observations from the world, coefficients $\gamma_{1}$ and $\gamma_{2}$ measure the impact of weather shocks on TFP in high-income countries. $\gamma_{1}^{\text {Low }}$ and $\gamma_{1}^{\text {Middle }}$ capture the difference in the impact of changes in temperatures, comparing with high-income countries, on TFP in LICs and middle-income countries, respectively. The overall impact of changes in temperatures on LICs, for example, is a linear combination of two coefficients: $\gamma_{1}+\gamma_{1}^{\text {Low }} .25$

Table 4 summarizes results from estimating equation (2). Column (1) regresses TFP growth rate on d.Temp only, assuming that all countries respond to weather shocks in the same way. The estimated coefficient is negative, -0.6, as expected, but it is not statistically significant. This is because the model does not allow different responses to weather shocks across countries. As a result, positive responses and negative responses worked in difference directions, resulting in an insignificant coefficient.

Column (2) introduces interaction terms with income-level dummies. Linear combinations of coefficients reported in the bottom of the table show that a $1^{\circ} \mathrm{C}$ rise in temperatures reduces the TFP growth rate by 2.7 percent in LICs. Middle-income countries also have a negative coefficient, but the magnitude is small and statistically insignificant. These negative temperature effects in LICs are consistent with previous empirical results. For example, Dell et al. (2012) show that rising temperatures had reduced the GDP growth rate of LICs. Cattaneo and Peri (2016) find that an increase in temperatures increased emigration from middle-income countries, possibly because agriculture productivity declined due to higher temperatures, which led to a greater incentive to emigrate from the countries.

\footnotetext{
${ }^{24}$ One may concern about correlation between temperatures and rainfalls, leading to a multicollinearity. However, correlation between these two variables is quite low. Using a sample of all countries, we find that correlation coefficients between d.Temp and d.Rainfall are -0.0885 for the period 1990-2015. Even if we restrict our sample to LICs, the correlation coefficient is -0.0959 for the same period. See Appendix F for more details.

${ }^{25}$ Similarly, $\gamma_{2}^{\text {Low }}$ and $\gamma_{2}^{\text {Middle }}$ measure the difference in the impact of changes in rainfalls, comparing with highincome countries, on TFP in LICs and middle-income countries, respectively. In order to identify the different impacts of climate across countries, the model needs to introduce interaction terms between income-level dummies and year fixed effects: $D_{i}^{\text {Low }} \theta_{t}$ and $D_{i}^{\text {Middle }} \theta_{t}$.
} 
Table 4: The Impact of Weather Shocks, Baseline Results

Dependent Variable $=100$ times Annual Agricultural TFP Growth Rate

\begin{tabular}{|c|c|c|c|c|c|}
\hline & $(1)$ & $(2)$ & (3) & $(4)$ & $(5)$ \\
\hline d.Temperature & -0.606 & -0.215 & -0.080 & -0.290 & -0.080 \\
\hline & $(0.447)$ & $(0.614)$ & $(0.426)$ & $(0.232)$ & $(0.428)$ \\
\hline \multirow[t]{2}{*}{ Low-income country dummy $\times$ d.Temperature } & & $-2.482 * *$ & $-2.340 * *$ & $-3.073 * * *$ & $-3.601 * * *$ \\
\hline & & $(1.121)$ & $(0.967)$ & $(1.107)$ & $(0.970)$ \\
\hline \multirow[t]{2}{*}{ Middle-income country dummy $\times$ d.Temperature } & & -0.404 & -0.451 & -0.608 & -0.650 \\
\hline & & $(0.296)$ & $(0.390)$ & $(0.790)$ & $(0.543)$ \\
\hline \multirow[t]{2}{*}{ Hot country dummy $\times$ d.Temperature } & & & & $1.619 *$ & \\
\hline & & & & $(0.848)$ & \\
\hline \multirow[t]{2}{*}{ Agricultural country dummy $\times$ d.Temperature } & & & & & 1.742 \\
\hline & & & & & $(1.464)$ \\
\hline \multirow[t]{2}{*}{ d.Rainfalls } & & & -2.069 & 2.051 & -2.069 \\
\hline & & & $(7.648)$ & $(5.846)$ & $(7.680)$ \\
\hline \multirow[t]{2}{*}{ Low-income country dummy $\times$ d.Rainfalls } & & & 7.919 & 9.074 & 8.494 \\
\hline & & & $(9.131)$ & $(9.602)$ & $(9.156)$ \\
\hline \multirow[t]{2}{*}{ Middle-income country dummy $\times$ d.Rainfalls } & & & 3.324 & 6.163 & 3.390 \\
\hline & & & (7.957) & $(9.483)$ & (7.988) \\
\hline \multirow[t]{2}{*}{ Hot country dummy $\times$ d.Rainfalls } & & & & $-7.839 *$ & \\
\hline & & & & $(4.681)$ & \\
\hline \multirow[t]{2}{*}{ Agricultural country dummy $\times$ d.Rainfalls } & & & & & -0.930 \\
\hline & & & & & $(2.583)$ \\
\hline Observations & 3,266 & 3,266 & 3,242 & 3,242 & 3,242 \\
\hline Countries & 141 & 141 & 141 & 141 & 141 \\
\hline$R$-squared & 0.011 & 0.012 & 0.013 & 0.029 & 0.016 \\
\hline \multicolumn{6}{|l|}{ Linear combination of coefficients, Temperature effects } \\
\hline \multirow{2}{*}{\multicolumn{2}{|c|}{ Low-income countries }} & $-2.697 * * *$ & $-2.419 * * *$ & $-3.363 * * *$ & $-3.680 * * *$ \\
\hline & & $(0.666)$ & $(0.661)$ & $(0.916)$ & $(0.868)$ \\
\hline \multirow{2}{*}{\multicolumn{2}{|c|}{ Middle-income countries }} & -0.618 & -0.530 & -0.898 & -0.730 \\
\hline & & $(0.633)$ & $(0.651)$ & $(0.693)$ & $(0.771)$ \\
\hline \multicolumn{6}{|l|}{ Linear combination of coefficients, Rainfall effects } \\
\hline \multirow[t]{2}{*}{ Low-income countries } & & & $5.850^{* *}$ & $11.12 * *$ & 6.425 \\
\hline & & & $(3.385)$ & $(5.077)$ & $(5.327)$ \\
\hline \multirow{2}{*}{\multicolumn{2}{|c|}{ Middle-income countries }} & & 1.254 & 8.213 & 1.321 \\
\hline & & & $(1.357)$ & $(5.220)$ & $(1.595)$ \\
\hline
\end{tabular}

Notes: All regressions include income-level dummies interacted with year fixed effects. Robust standard errors, clustered in two ways, at the country-level and the region-level, are in parentheses. Country classifications are based on the World Bank's classification. Hot countries are defined as countries having above median average temperature in 1990. Agricultural countries are defined as those having a share of agricultural value-added to GDP above the 75th percentile in 1990. Temperatures are in degrees Celsius and rainfalls are in units of $100 \mathrm{~mm}$ per month. ***, $* *$, and * indicate statistical significance at the $1 \%, 5 \%$, and $10 \%$ level, respectively. See the main text for data sources.

The significant weather effects are presumably because LICs employ agricultural technologies that are more sensitive to climatic conditions, in the sense that they use less machinery capital, 
fertilizers, and are less able to hedge against commodity price risk compared to richer countries. Mendelsohn et al. (2001) and Mendelsohn et al. (2006) argue that economic development reduces vulnerability of agricultural production to climatic changes. Another possible explanation is irrigation. Previous articles find that irrigated farms are less sensitive to weather shocks (e.g., Wang et al., 2009; Kurukulasuriya et al., 2006). LICs may have less irrigation, which possibly led to a sensitive reaction to weather shocks.

One may claim that higher temperatures negatively affect LICs just because they are located in hot areas such as Sub-Saharan Africa. In order to control for the level of temperatures, by following Dell et al. (2012), we introduce interaction terms between climate variables and a dummy variable taking unity if the country is a "hot country". Hot countries are defined as those having above median average temperature in the start year of the sample (1991). Column (4) indicates that adding the interaction terms does not change our baseline result qualitatively.

The next concern comes from the level of importance of agriculture in each country. The significant climate effects in LICs may be just because those countries are more agriculturalbased than other countries. In order to examine if that is the case, we introduce interaction terms with a dummy variable taking unity if the share of value-added from the agricultural sector in GDP is greater than the 75th percentile of the sample in 1990. ${ }^{26}$ The last column shows that adding the interaction terms does not change our baseline results much.

Next, we show that our results are robust to a wide range of different samples and specifications. Table 5 addresses various concerns that might affect our conclusion. The first two columns show results from estimating the baseline model by replacing the dependent variable with the agricultural value-added growth and the $\mathrm{TFP}_{b}$ growth rate as in the previous section. Although the coefficients change slightly, we obtain essentially the same results.

Column (3) reports a result from estimating the baseline model with excluding countries with greater share of oil production. Column (4) excludes all samples from commodity price hikes. Column (5) employs different income-level classification - the baseline specification uses the income-level classification from the World Bank while column (3) uses our own definitions based on income-level percentiles from $1995 .{ }^{27}$ Column (6) adds explanatory variables from

\footnotetext{
${ }^{26}$ The reason for different cutoffs - the $50^{\text {th }}$ percentile for the hot country dummy and the $75^{\text {th }}$ percentile for the agriculture-based country - is that the distribution of the share of agricultural value-added is skewered and it takes small values for majority of countries. Therefore, we choose the $75^{\text {th }}$ percentile for the cutoff to be defined as an agriculture-based economy.

${ }^{27}$ The reason for choosing 1995 as the base year is as follows. First, we define country groups based on one of the earliest years of the sample in order to avoid possible endogeneity issues arising from endogenous change in countries' income levels due to weather shocks. Second, however, choosing 1991 as the base year reduces our sample size because there are some missing observations on GDP per capita in 1991. Therefore, in order to cover as many observations as possible and to have a benchmark year from earliest years in the sample, we choose 1995 as our base year to define country groups.
} 
Table 2 to control for other possible determinants of TFP. ${ }^{28}$ Overall, Table 5 shows that our results are robust.

\author{
Table 5: The Impact of Weather Shocks, Robustness Checks
}

Dependent Variable $=100$ times Annual Agricultural TFP Growth Rate or 100 times Annual Agricultural Value-Added Growth Rate

\begin{tabular}{|c|c|c|c|c|c|c|}
\hline \multirow{3}{*}{ Dependent variable } & \multicolumn{2}{|c|}{$\begin{array}{l}\text { Baseline specification } \\
\text { \& baseline sample }\end{array}$} & $\begin{array}{l}\text { Excluding oil } \\
\text { producers }\end{array}$ & \multicolumn{2}{|c|}{$\begin{array}{cc}\begin{array}{c}\text { Excluding the } \\
\text { period of }\end{array} & \text { groups based } \\
\text { commodity } & \text { on } \\
\text { price hikes } & \text { percentiles } \\
\end{array}$} & \multirow[t]{2}{*}{$\begin{array}{l}\text { Controlloing } \\
\text { for other } \\
\text { determinants } \\
\text { of TFP } \\
\end{array}$} \\
\hline & $\begin{array}{l}\text { Value-added } \\
\text { growth rate }\end{array}$ & $\begin{array}{l}\mathrm{TFP}_{b} \\
\text { growth rate }\end{array}$ & \multicolumn{3}{|c|}{ TFP growth rate } & \\
\hline & $(1)$ & $(2)$ & (3) & (4) & $(5)$ & $(6)$ \\
\hline d.Temp. & 0.290 & 0.231 & 0.073 & 0.012 & 0.498 & -0.423 \\
\hline & $(0.239)$ & $(0.183)$ & $(0.415)$ & $(0.425)$ & $(0.487)$ & $(0.379)$ \\
\hline Low-income country dummy $\times$ d.Temp. & $-2.876^{* * *}$ & $-2.519 * * *$ & $-1.567 *$ & $-1.744 * *$ & $-2.375 * * *$ & $-2.378 * * *$ \\
\hline & $(1.092)$ & $(0.673)$ & $(0.951)$ & $(0.695)$ & $(0.428)$ & $(0.604)$ \\
\hline \multirow[t]{2}{*}{ Middle-income country dummy $\times$ d.Temp. } & $-0.992 * *$ & -0.489 & $-0.965 * * *$ & $-0.637 *$ & $-1.217 * *$ & -0.884 \\
\hline & $(0.473)$ & $(0.482)$ & $(0.320)$ & $(0.353)$ & $(0.598)$ & $(1.661)$ \\
\hline \multirow[t]{2}{*}{ d.Rainfalls } & $2.856^{*}$ & 2.210 & -5.792 & -4.479 & -6.107 & $4.355 * * *$ \\
\hline & $(1.617)$ & $(2.176)$ & $(7.315)$ & $(8.954)$ & $(7.538)$ & $(1.570)$ \\
\hline \multirow[t]{2}{*}{ Low-income country dummy $\times$ d. Rainfalls } & 3.235 & 3.152 & 11.70 & 10.79 & 10.45 & 9.867 \\
\hline & $(2.201)$ & $(3.396)$ & $(7.462)$ & $(10.140)$ & $(7.893)$ & $(6.912)$ \\
\hline \multirow[t]{2}{*}{ Middle-income country dummy $\times$ d.Rainfalls } & $-2.037 * *$ & -0.837 & 6.552 & 6.151 & 8.087 & $-4.732 * *$ \\
\hline & $(1.028)$ & $(2.005)$ & $(7.614)$ & $(9.207)$ & $(7.442)$ & $(2.045)$ \\
\hline Observations & 4,066 & 3,410 & 2,661 & 2,423 & 3,242 & 1,382 \\
\hline Countries & 158 & 147 & 141 & 141 & 141 & 61 \\
\hline$R$-squared & 0.025 & 0.023 & 0.017 & 0.012 & 0.013 & 0.038 \\
\hline \multicolumn{7}{|c|}{ Linear combination of coefficients, Temperature effects } \\
\hline \multirow[t]{2}{*}{ Low-income countries } & $-2.586 * *$ & $-2.288 * * *$ & $-1.494 *$ & $-1.732 * * *$ & $-1.877 * * *$ & $-2.801 * * *$ \\
\hline & $(1.044)$ & $(0.636)$ & $(0.842)$ & $(0.427)$ & $(0.383)$ & $(0.473)$ \\
\hline \multirow[t]{2}{*}{ Middle-income countries } & -0.702 & -0.258 & -0.892 & -0.625 & -0.719 & -1.307 \\
\hline & $(0.521)$ & $(0.551)$ & $(0.489)$ & $(0.267)$ & $(0.732)$ & $(1.854)$ \\
\hline \multicolumn{7}{|l|}{ Linear combination of coefficients, Rainfall effects } \\
\hline \multirow[t]{2}{*}{ Low-income countries } & $6.092 * *$ & $5.361 * *$ & $5.907 * * *$ & $6.311 * * *$ & $4.345^{* *}$ & $14.222 * *$ \\
\hline & $(2.648)$ & $(2.722)$ & $(1.302)$ & $(3.377)$ & $(1.769)$ & $(6.739)$ \\
\hline \multirow[t]{2}{*}{ Middle-income countries } & 0.820 & 1.373 & 0.760 & 1.672 & 1.980 & -0.377 \\
\hline & $(1.014)$ & $(1.125)$ & $(1.300)$ & $(1.805)$ & $(1.700)$ & $(1.312)$ \\
\hline
\end{tabular}

Notes: All regressions include income-level dummies interacted with year fixed effects. Robust standard errors, clustered in two ways, at the country-level and the region-level, are in parentheses. Temperatures are in degrees Celsius and rainfalls are in units of $100 \mathrm{~mm}$ per month. $* * *, * *$, and $*$ indicate statistical significance at the $1 \%, 5 \%$, and $10 \%$ level, respectively. See the main text for data sources.

\footnotetext{
${ }^{28}$ Additional explanatory variables in column (6) include the capital-to-labor ratio, the taxes-to-value added ratio, and the subsidies-to-value added ratio. These variables are taken from the EORA and available for a large number of countries. We do not introduce fertilizers \& pesticides and the political instability index because these variables are not available for many of LICs and adding these significantly limits the number of observations.
} 


\section{Importing Inputs Mitigates the Negative Weather Effects: Theory}

The previous sections consider the impact of imported inputs and weather shocks individually, by closely following regression models from the literature. We further investigate interactions between these two factors in explaining agricultural TFP. This section presents a simple theoretical model helps clarify how imported inputs and weather shocks interact to affect TFP.

We start from the agricultural production function in Section II:

$$
Y_{i t}=A_{i t}\left(K_{i t}\right)^{\alpha_{i t}^{K}}\left(L_{i t}\right)^{\alpha_{i t}^{L}}\left(T_{i t}\right)^{\alpha_{i t}^{T}}
$$

where agricultural TFP, $A_{i t}$, is now described as a function of local temperatures Temp $i t$, local rainfalls Rain $_{i t}$, and quality of intermediate inputs $\phi_{i t}::^{29}$

$$
A_{i t}=A\left(\text { Temp }_{i t}, \text { Rain }_{i t}, \phi_{i t}\right) \text {. }
$$

The overall quality of intermediate inputs $\phi_{i t}$ is a weighted average of quality of domestic inputs $\phi_{i t}^{D}$ and that of imported inputs $\phi_{i t}^{I m}$ :

$$
\phi_{i t}=\vartheta_{i t}^{D} \phi_{i t}^{D}+\vartheta_{i t}^{I m} \phi_{i t}^{I m}
$$

where the weights are the share of domestic inputs to the total value of inputs, $\vartheta_{i t}^{D}=I_{i t}^{D} /\left(I_{i t}^{D}+\right.$ $\left.I_{i t}^{I m}\right)$ and $\vartheta_{i t}^{I m}=I_{i t}^{I m} /\left(I_{i t}^{D}+I_{i t}^{I m}\right)$ is the share of imported inputs.

We argue that a higher share of imported inputs reduces TFP's sensitivity to weather shocks. In other words, because higher temperatures reduce TFP, $\partial A_{i t} / \partial T e m p_{i t}<0$, and rainfalls increase TFP, $\partial A_{i t} / \partial \operatorname{Rain}_{i t}>0$, we have $\frac{\partial^{2} A_{i t}}{\partial T e m p_{i t} \partial \vartheta_{i t}^{I m}}>0$ and $\frac{\partial^{2} A_{i t}}{\partial \operatorname{Rain}_{i t} \partial \vartheta_{i t}^{I m}}<0$. Although the directions of the effects are opposite between the two weather shocks, the exact same discussions apply to these two. Therefore, this section focuses on the effect of temperature shocks only.

The effect of rising temperatures on agricultural TFP is obtained by differentiating TFP $A_{i t}$ with respect to $T e m p_{i t}$ :

$$
\frac{\partial A_{i t}}{\partial T e m p_{i t}}=\frac{\partial A}{\partial T e m p_{i t}}+\frac{\partial A}{\partial \phi_{i t}}\left(1-\vartheta_{i t}^{I m}\right) \frac{\partial \phi_{i t}^{D}}{\partial T e m p_{i t}}+\frac{\partial A}{\partial \phi_{i t}} \vartheta_{i t}^{I m} \frac{\partial \phi_{i t}^{M}}{\partial T e m p_{i t}},
$$

where we plugged $\vartheta_{i t}^{D}=1-\vartheta_{i t}^{I m}$. The first term is the direct effect of rising temperatures on agricultural TFP; the second term indicates the indirect effect through the quality domestic inputs; and the third term is the indirect effect through the quality of imported inputs. Assuming that local temperature shocks do not affect quality of imported inputs, $\partial \phi_{i t}^{M} / \partial T e m p_{i t}=0$, the previous equation becomes:

$$
\frac{\partial A_{i t}}{\partial T e m p_{i t}}=\frac{\partial A}{\partial T e m p_{i t}}+\frac{\partial A}{\partial \phi_{i t}}\left(1-\vartheta_{i t}^{I m}\right) \frac{\partial \phi_{i t}^{D}}{\partial T e m p_{i t}} .
$$

By differentiating this equation with respect to $\vartheta_{i t}^{I m}$, we obtain

\footnotetext{
${ }^{29}$ The previous section estimates the impact of weather shocks on the TFP growth rate and Appendix E provides a theoretical background for the regression equation. The theoretical setup in this section becomes consistent with the empirical model by specifying the TFP function as follows: $A_{i t}=A\left(\operatorname{Temp}_{i t}, \operatorname{Rain}_{i t}, \phi_{i t}\right)=$ $A_{i t-1} D\left(T e m p_{i t}, \operatorname{Rain}_{i t}, \phi_{i t}\right)$, TFP from the previous year times a damage function from weather shocks. Many other potential factors may affect TFP. However, we focus on these three variables as determinants of TFP.
} 


$$
\frac{\partial^{2} A_{i t}}{\partial T e m p_{i t} \partial \vartheta_{i t}^{I m}}=\underbrace{\frac{\partial^{2} A}{\partial T e m p_{i t} \partial \vartheta_{i t}^{I m}}}_{\begin{array}{c}
\text { Direct } \\
\text { productivity effect }
\end{array}}+\underbrace{\left(-\frac{\partial A}{\partial \phi_{i t}} \frac{\partial \phi_{i t}^{D}}{\partial T e m p_{i t}}\right)}_{\begin{array}{c}
\text { Diversification } \\
\text { effect }
\end{array}}+\underbrace{\frac{\partial A}{\partial \phi_{i t}}\left(1-\vartheta_{i t}^{I m}\right) \frac{\partial^{2} \phi_{i t}^{D}}{\partial T e m p_{i t} \partial \vartheta_{i t}^{I m}}}_{\begin{array}{c}
\text { Synargies between } \\
\text { domestic and imported inputs }
\end{array}} .
$$

where we assume $\partial^{2} A /\left(\partial \phi_{i t} \partial \vartheta_{i t}^{I m}\right)=0 .{ }^{30}$ Because higher temperatures reduce agricultural TFP, $\partial A_{i t} / \partial T e m p_{i t}<0$, and a greater share of imported inputs reduces the negative temperature effects, we argue $\partial^{2} A_{i t} /\left(\partial T e m p_{i t} \partial \vartheta_{i t}^{I m}\right)>0$.

This positive cross derivative comes from three effects. First, a greater share of imported inputs directly reduces the negative temperature effects, $\partial^{2} A /\left(\partial T e m p_{i t} \partial \vartheta_{i t}^{I m}\right)>0$. Better production technologies embedded in imported inputs increase productivity, making agricultural production technology less sensitive to weather shocks. As shown in Section IV, a greater share of imported inputs increases agricultural TFP. Although we do not examine the direct effect on the climate sensitivity, we suppose a greater TFP makes agricultural production less sensitive to weather shocks. We refer to this effect as the direct productivity effect.

Second, a greater share of imported inputs increases the share of inputs that are not affected by local temperature shocks. As a result, this de-localization of inputs reduces the sensitivity of agricultural TFP to weather shocks, reflected in the second term: $-\frac{\partial A}{\partial \phi_{i t}} \frac{\partial \phi_{i t}^{D}}{\partial T p_{i t}}$, which is positive because $\partial \phi_{i t}^{D} / \partial T e m p_{i t}<0$. This is the same mechanism as Caselli et al. (2015), showing that a country can reduce exposure to domestic shocks therefore income volatility by diversifying source countries of imports. Their analyses include all macroeconomic shocks but there must be similar mechanisms in the context of weather shocks. We call this second channel the diversification effect.

Third, the last term of the previous equation is positive if $\partial^{2} \phi_{i t}^{D} /\left(\partial T e m p_{i t} \partial \vartheta_{i t}^{I m}\right)>0$ because $\frac{\partial A}{\partial \phi_{i t}}\left(1-\vartheta_{i t}^{I m}\right)>0$. This captures synergies between domestic inputs and imported inputs. A local final good producer is an intermediate good provider for other local final good producers. Therefore, increased productivity of domestic intermediate good producers raises productivity of domestic final good producers, making them less sensitive to weather shocks. ${ }^{31}$ We refer to this as synergies between imported inputs and domestic inputs.

\footnotetext{
${ }^{30}$ This means that a change in the share of imported inputs does not affect the elasticity of agricultural TFP, $A_{i t}$, with respect to the overall quality of intermediate inputs $\phi_{i t}$.

${ }^{31}$ This effect is present in a model where all final good varieties are used as intermediate inputs as in Eaton and Kortum (2003). Goldberg et al. (2010) find that new imported inputs facilitate domestic product creation. A greater number of domestically produced varieties due to new imported inputs would increase productivity of domestic firms if its production function is a CES form as in Kasahara and Rodrigue (2008).
} 


\section{Importing Inputs Mitigates the Negative Weather Effects: Evidence}

We have clarified the channels a higher share of imported inputs makes countries less sensitive to weather shocks. This section investigates if imported inputs have such effects by only using observations from LICs where we find significant effects of weather shocks.

In order to test the theoretical possibilities, we estimate the following equation:

$$
\begin{gathered}
g_{i, t}^{T F P}=\pi_{0}+\pi_{1} d \cdot \operatorname{Temp}_{i, t}+\pi_{1}^{\text {LowIm }}\left[\operatorname{d.Temp}_{i, t} D_{i}^{\text {LowIm }}\right]+ \\
+\pi_{2} d \cdot \operatorname{Rain}_{i, t}+\pi_{2}^{\text {LowIm }}\left[\text { d.Rain }_{i, t} D_{i}^{\text {Low }}\right]+D_{i}^{\text {LowIm }}+D_{i}^{\text {LowIM }} \theta_{t}+u_{i, t},
\end{gathered}
$$

where $g_{i, t}^{T F P}, d . T e m p_{i, t}$, and $d$. Rain $i, t$ follow the same definitions as for equation (3). $u_{i, t}$ denotes an error term. $D_{i}^{\text {LowIm }}$ is a dummy variable taking unity if country $i$ 's imported inputs-tototal inputs share is less than the $50^{\text {th }}$ percentile of LICs in the start year of the sample (1991). We use the data from 1991 to construct $D_{i}^{\text {LowIm }}$ in order to deal with possible endogenous changes in the share of imported inputs due to weather shocks. Interaction terms between $D_{i}^{\text {LowIM }}$ and year dummies $\theta_{t}$ are also introduced. $\pi_{0}, \pi_{1}^{\text {LowIm }}, \pi_{2}$, and $\pi_{2}^{\text {LowIm }}$ are coefficients to be estimated.

\begin{tabular}{|c|c|c|c|c|c|c|}
\hline \multirow{3}{*}{ Dependent variable } & \multicolumn{3}{|c|}{$\begin{array}{l}\text { Baseline specification \& } \\
\text { baseline sample }\end{array}$} & \multirow{2}{*}{$\begin{array}{c}\begin{array}{c}\text { Excluding } \\
\text { oil } \\
\text { producers }\end{array} \\
\mathrm{TH}\end{array}$} & \multirow{2}{*}{$\begin{array}{l}\text { Excluding } \\
\text { the period of } \\
\text { commodity } \\
\text { price hikes }\end{array}$} & \multirow{2}{*}{$\begin{array}{c}\text { Controlloing } \\
\text { for other } \\
\text { determinants } \\
\text { of TFP }\end{array}$} \\
\hline & $\begin{array}{c}\text { TFP } \\
\text { growth rate }\end{array}$ & $\begin{array}{l}\text { Value-added } \\
\text { growth rate }\end{array}$ & $\begin{array}{c}\mathrm{TFP}_{b} \\
\text { growth rate }\end{array}$ & & & \\
\hline & (1) & (2) & (3) & (4) & (5) & (6) \\
\hline \multirow[b]{2}{*}{ Lower share of imported inputs $\times$ d.Temp. } & $\begin{array}{c}0.631 \\
(0.849)\end{array}$ & $\begin{array}{c}0.554 \\
(0.639)\end{array}$ & $\begin{array}{c}0.479 \\
(0.755)\end{array}$ & $\begin{array}{c}0.898 \\
(0.612)\end{array}$ & $\begin{array}{l}-0.525 \\
(0.493)\end{array}$ & $\begin{array}{c}0.618 \\
(0.811)\end{array}$ \\
\hline & $\begin{array}{l}-4.915 * * * \\
(0.977)\end{array}$ & $\begin{array}{c}-5.429 * * * \\
(1.780)\end{array}$ & $\begin{array}{c}-4.546 * * * \\
(1.065)\end{array}$ & $\begin{array}{c}-4.790 * * * \\
(0.402)\end{array}$ & $\begin{array}{c}-1.811 * * \\
(0.817)\end{array}$ & $\begin{array}{c}-4.963 * * * \\
(0.971)\end{array}$ \\
\hline d.Rainfalls & $\begin{array}{c}1.593 \\
(2.465)\end{array}$ & $\begin{array}{c}3.646 \\
(3.792)\end{array}$ & $\begin{array}{c}1.578 \\
(3.118)\end{array}$ & $\begin{array}{c}0.748 \\
(0.844)\end{array}$ & $\begin{array}{c}1.198 \\
(2.529)\end{array}$ & $\begin{array}{c}1.580 \\
(2.466)\end{array}$ \\
\hline Lower share of imported inputs $\times$ d.Rainfalls & $\begin{array}{c}11.96 * * * \\
(4.563)\end{array}$ & $\begin{array}{l}8.574^{*} \\
(4.905)\end{array}$ & $\begin{array}{l}12.02 * * \\
(4.689)\end{array}$ & $\begin{array}{l}8.142 * \\
(4.576)\end{array}$ & $\begin{array}{c}14.27 * * * \\
(4.904)\end{array}$ & $\begin{array}{c}11.99 * * * \\
(4.587)\end{array}$ \\
\hline Lower share of imported inputs dummy & $\begin{array}{l}-0.377 \\
(0.626)\end{array}$ & $\begin{array}{c}0.356 \\
(0.567)\end{array}$ & $\begin{array}{l}-0.381 \\
(0.567)\end{array}$ & $\begin{array}{l}-0.051 \\
(0.576)\end{array}$ & $\begin{array}{c}-0.890 * \\
(0.482)\end{array}$ & $\begin{array}{l}-0.245 \\
(0.388)\end{array}$ \\
\hline Observations & 557 & 621 & 557 & 498 & 415 & 557 \\
\hline Countries & 24 & 24 & 24 & 21 & 24 & 24 \\
\hline$R$-squared & 0.086 & 0.086 & 0.086 & 0.096 & 0.069 & 0.094 \\
\hline \multicolumn{7}{|c|}{ Linear combination of coefficients, Temperature effects } \\
\hline Lower share of imported inputs & $\begin{array}{c}-4.284 * * * \\
(0.850)\end{array}$ & $\begin{array}{c}-4.875 * * * \\
(1.559)\end{array}$ & $\begin{array}{c}-4.067 * * * \\
(0.940)\end{array}$ & $\begin{array}{c}-3.891 * * * \\
(0.471)\end{array}$ & $\begin{array}{c}-2.336 * * * \\
(0.678)\end{array}$ & $\begin{array}{c}-4.345^{* * *} \\
(0.868)\end{array}$ \\
\hline \multicolumn{7}{|l|}{ Linear combination of coefficients, Rainfall effects } \\
\hline Lower share of imported inputs & $\begin{array}{c}13.56^{* * *} \\
(3.943)\end{array}$ & $\begin{array}{c}12.22 * * * \\
(3.639)\end{array}$ & $\begin{array}{c}13.60 * * * \\
(3.751)\end{array}$ & $\begin{array}{l}8.889^{*} \\
(4.802)\end{array}$ & $\begin{array}{c}15.46^{* * * *} \\
(4.920)\end{array}$ & $\begin{array}{c}13.57 * * * * \\
(4.001)\end{array}$ \\
\hline
\end{tabular}

Table 6: Weather Shocks and Imported Inputs, LICs

Notes: All regressions include country dummies interacted with year dummies and use observations from LICs only. Robust standard errors, clustered at the country-level, are in parentheses. Temperatures are in degrees Celsius and rainfalls are in units of $100 \mathrm{~mm}$ per month. ***,**, and * indicate statistical significance at the $1 \%, 5 \%$, and $10 \%$ level, respectively. See the main text for data sources. 
Because we use a sample from LICs only and introduce the interaction term, $d . \operatorname{Temp}_{i, t} D_{i}^{\operatorname{Low} I m}$, the coefficient $\pi_{1}$ measures the temperature effect in LICs with higher share of imported inputs. $\pi_{1}^{\text {LowIm }}$ captures "the temperature effect for countries with lower shares of imported inputs" minus "that for those with higher share of imported inputs". As a result, a linear combination of coefficients, $\pi_{1}+\pi_{1}^{\text {LowIm }}$, is the temperature effect for LICs with lower shares of imported inputs. A similar interpretation applies to the rainfall variables.

Table 6 presents estimation results. Column (1) shows that a $1{ }^{\circ} \mathrm{C}$ increase in average temperatures reduces the TFP growth rate by 4.3 percent in countries with lower shares of imported inputs (see the linear combination of coefficients in the bottom of the table). Moreover, a $100 \mathrm{~mm}$ increase in monthly rainfalls increases the TFP growth rate by 13.6 percent. The results also suggest that weather shocks have no significant effects on countries with higher share of imported inputs even though all countries in the sample are from LICs.

Columns (2) and (3) use the same sample and the same explanatory variables as for column (1) but they use the value-added growth rate and the $\mathrm{TFP}_{b}$ growth rate. respectively. Results are essentially the same as for column (1). Columns (4)-(6) use the same dependent variable as for column (1) but they employ different samples of observations or controlling for additional explanatory variables as we have done in the previous section. ${ }^{32}$ Again, results are robust.

One may claim that imported inputs actually do not mitigate weather shocks and the variable is just working as a proxy of something else. We consider three possibilities that our baseline results are spurious. First, it is possible that (Imported inputs)/(Total inputs) merely captures the countries' openness to import. Because imports in general have pro-competitive effects and increase productivity, the results may just be capturing countries' propensity to import from abroad, not the impact of imported inputs.

Second, possibly relatively richer countries within the LICs tend to use more imported inputs and these countries are less sensitive to weather shocks for some other reason. If that is the case, our baseline results could be coming from countries' initial income levels, not the share of imported inputs. Third, a higher share of imported inputs may be related with countries' initial technology levels and countries with better production technologies are possibly less vulnerable to weather shocks. If so, the results may just be showing different temperature effects stemming from countries' differences in initial technology levels.

In order to examine if these concerns are valid, we estimate the following equation:

$$
\begin{aligned}
& g_{i, t}^{T F P}=\rho_{1} d . \text { Temp }_{i, t}+\rho_{1}^{\text {LowIm }}\left[d . \text { Temp }_{i, t} D_{i}^{\text {LowIm }}\right]+\rho_{2} d \cdot \text { Rain }_{i, t}+\rho_{2}^{\text {LowIm }}\left[d . \text { Rain }_{i, t} D_{i}^{\text {LowIm }}\right] \\
& +\rho_{1}^{\text {LowAggIm }}\left[d . \text { Temp }_{i, t} D_{i}^{\text {LowAggIm }}\right]+\rho_{2}^{\text {LowAggIm }}\left[d . \text { Rain }_{i, t} D_{i}^{\text {LowAggIm }}\right] \\
& +D_{i}^{\text {LowIm }}+D_{i}^{\text {LowAggIm }}+\rho_{0}+\tilde{u}_{i, t},
\end{aligned}
$$

where $D_{i}^{\text {Low AggIm }}$ denotes a dummy variable taking unity if the country's aggregate imports-toGDP ratio is less than the $50^{\text {th }}$ percentile among LICs in 1991; $\rho_{0}, \rho_{1}, \rho_{1}^{\text {LowIm }}, \rho_{1}^{\text {LowAggIm }}, \rho_{2}$, $\rho_{2}^{\text {LowIm }}$, and $\rho_{2}^{\text {LowAggIm }}$ are parameters to be estimated; $\tilde{u}_{i, t}$ indicates an error term.

\footnotetext{
32 The same set of additional explanatory variables as for column (6) in Table 5 is introduced.
} 
Table 7: Weather Shocks and Imported Inputs, LICs, Robustness Checks

Dependent Variable $=100$ times Annual Agricultural TFP Growth Rate

\begin{tabular}{|c|c|c|c|c|c|c|}
\hline & \multicolumn{2}{|c|}{ Imports-to-GDP ratio } & \multicolumn{2}{|c|}{ Initial income levels } & \multicolumn{2}{|c|}{ Initial TFP levels } \\
\hline & $(1)$ & $(2)$ & (3) & $(4)$ & $(5)$ & $(6)$ \\
\hline d.Temp. & $\begin{array}{l}-4.281 * \\
(2.529)\end{array}$ & $\begin{array}{c}-1.001 \\
(3.014)\end{array}$ & $\begin{array}{c}-0.947 \\
(1.168)\end{array}$ & $\begin{array}{l}1.234 * \\
(0.747)\end{array}$ & $\begin{array}{l}-2.619 \\
(1.763)\end{array}$ & $\begin{array}{c}0.568 \\
(2.157)\end{array}$ \\
\hline Lower share of imported inputs $\times$ d.Temp. & & $\begin{array}{c}-4.619 * * * \\
(1.298)\end{array}$ & & $\begin{array}{c}-4.568 * * * \\
(1.335)\end{array}$ & & $\begin{array}{c}-4.933 * * * \\
(0.961)\end{array}$ \\
\hline Lower imports-to-GDP ratio $\times$ d.Temp. & $\begin{array}{c}3.259 \\
(2.283)\end{array}$ & $\begin{array}{c}2.580 \\
(2.710)\end{array}$ & & & & \\
\hline Lower initial income level $\times$ d.Temp. & & & $\begin{array}{c}-3.625 * * * \\
(1.302)\end{array}$ & $\begin{array}{c}-1.809 \\
(1.303)\end{array}$ & & \\
\hline Lower initial TFP level $\times$ d.Temp. & & & & & $\begin{array}{c}0.421 \\
(3.224)\end{array}$ & $\begin{array}{c}0.178 \\
(3.067)\end{array}$ \\
\hline d.Rainfalls & $\begin{array}{c}15.96^{* * * *} \\
(4.684)\end{array}$ & $\begin{array}{c}12.03 * * * \\
(4.287)\end{array}$ & $\begin{array}{c}7.688 \\
(7.803)\end{array}$ & $\begin{array}{c}5.752 \\
(6.199)\end{array}$ & $\begin{array}{c}5.778 \\
(4.280)\end{array}$ & $\begin{array}{c}1.826 \\
(3.128)\end{array}$ \\
\hline Lower share of imported inputs $\times$ d.Rainfalls & & $\begin{array}{c}12.20 * * * \\
(2.944)\end{array}$ & & $\begin{array}{c}17.11 * * * \\
(5.899)\end{array}$ & & $\begin{array}{l}11.99 * * \\
(4.767)\end{array}$ \\
\hline Lower imports-to-GDP $\times$ d.Rainfalls & $\begin{array}{c}-14.90 * * \\
(6.049)\end{array}$ & $\begin{array}{c}-15.41 * * * \\
(5.144)\end{array}$ & & & & \\
\hline Lower initial income level $\times$ d.Rainfalls & & & $\begin{array}{l}-3.900 \\
(7.447)\end{array}$ & $\begin{array}{c}-12.02 * \\
(6.588)\end{array}$ & & \\
\hline Lower initial TFP level $\times$ d.Rainfalls & & & & & $\begin{array}{c}-0.032 \\
(8.487) \\
\end{array}$ & $\begin{array}{l}-1.724 \\
(7.708) \\
\end{array}$ \\
\hline Observations & 557 & 557 & 557 & 557 & 557 & 557 \\
\hline Countries & 24 & 24 & 24 & 24 & 24 & 24 \\
\hline$R$-squared & 0.084 & 0.098 & 0.077 & 0.092 & 0.071 & 0.086 \\
\hline \multicolumn{7}{|c|}{ Linear combination of coefficients, Temperature effects } \\
\hline Lower share of imported inputs & & $\begin{array}{c}-5.620 * * \\
(2.853)\end{array}$ & & $\begin{array}{c}-3.334 * * * \\
(1.283)\end{array}$ & & $\begin{array}{c}-4.366 * * \\
(1.841)\end{array}$ \\
\hline Lower imports-to-GDP ratio & $\begin{array}{c}-1.022 * * * \\
(0.271)\end{array}$ & $\begin{array}{c}1.579 \\
(0.812)\end{array}$ & & & & $\begin{array}{c}0.746 \\
(1.134)\end{array}$ \\
\hline Lower initial income levels & & & $\begin{array}{c}-4.573 * * * \\
(0.332)\end{array}$ & $\begin{array}{c}-0.575 \\
(1.435)\end{array}$ & & \\
\hline Lower initial TFP levels & & & & & $\begin{array}{c}-2.198 \\
(1.771)\end{array}$ & \\
\hline \multicolumn{7}{|l|}{ Linear combination of coefficients, Rainfall effects } \\
\hline Lower share of imported inputs & & $\begin{array}{c}24.23 * * * \\
(5.155)\end{array}$ & & $\begin{array}{c}22.86 * * * \\
(5.922)\end{array}$ & & $\begin{array}{c}13.82 * * * \\
(4.797)\end{array}$ \\
\hline Lower imports-to-GDP ratio & $\begin{array}{c}1.062 \\
(2.280)\end{array}$ & $\begin{array}{c}-3.375 * * * \\
(1.284)\end{array}$ & & & & \\
\hline Lower initial income levels & & & $\begin{array}{c}3.788 * * * \\
(1.325)\end{array}$ & $\begin{array}{l}-6.270 \\
(6.060)\end{array}$ & & \\
\hline Lower initial TFP levels & & & & & $\begin{array}{c}5.746 \\
(5.876)\end{array}$ & $\begin{array}{c}0.102 \\
(5.897)\end{array}$ \\
\hline
\end{tabular}

Notes: The dependent variable is the TFP growth rate. All regressions include a constant term and interaction terms between year dummies and each of the dummy variables. It uses observations from LICs only. Robust standard errors, clustered at the country-level, are in parentheses. Temperatures are in degrees Celsius and rainfalls are in units of $100 \mathrm{~mm}$ per month. ***,**, and * indicate statistical significance at the $1 \%, 5 \%$, and $10 \%$ level, respectively. See the main text for data sources. 
Figure 6: Weather Shocks and Annual TFP Growth Rates, LICs


Notes: The figures show the relationship between annual TFP growth rates - in the vertical axis - and annual changes in temperatures (Panel A) and rainfalls (Panel B) - in the horizontal axis. The sample comes from LICs during 1991-2015. 
Estimating equation (4) answers if the first story is the main cause of the baseline results. In order to examine if the second and third stories are true, we make a dummy variable taking unity if the country's initial GDP per capita is less than the $50^{\text {th }}$ percentile among LICs, $D_{i}^{\text {LowGDPpc }}$, and a dummy variable taking unity if the country's initial TFP level is less than the $50^{\text {th }}$ percentile among the group of countries, $D_{i}^{\text {LowTFP }}$. Estimating equation (4) by replacing $D_{i}^{\text {LowAggIm }}$ with $D_{i}^{\text {LowGDPPC }}$ (or $D_{i}^{\text {LowTFP }}$ ) answers if the second (or the third) concern is valid or not. ${ }^{33}$ These dummy variables are constructed based on the data from the WDI and our TFP estimates. $^{34}$

Regression results are shown in Table 7. Columns (1) and (2) display results from estimating regressions controlling for the aggregate imports-to-GDP ratio. Column (1) introduces interaction terms with the aggregate imports-to-GDP ratio only and shows temperature effects are not statistically different across the two groups of countries - countries with higher aggregate imports-to-GDP ratio and those with lower ones. It also shows that the rainfall effects are greater for countries with lower aggregate imports-to-GDP ratio. Column (2) controls for both the imported inputs-to-total inputs ratio and the aggregate imports-to-GDP ratio. However, the effect of imported inputs remain significant. These results imply that our results are not coming from cross-country differences in propensity to import from abroad in general.

Finally, columns (5) and (6) consider the initial agricultural TFP levels. Results in column (5) imply that there is no systematic difference in weather shocks across low TFP countries and high TFP countries within the LICs. Furthermore, column (6) shows that, even after controlling for the initial TFP levels, the effects of imported inputs are similar to the baseline result. These considerations support the idea that our baseline results are caused by cross-country differences in the share of imported inputs. Appendix G conducts more robustness checks using different samples and concerning the way we construct the dummy variables.

Figure 6 visually describe the baseline results, where Panel A shows the relationship between the TFP growth rate and annual changes in temperatures and Panel B presents the one for rainfalls. It indicates that steeper temperature effects and rainfall effects come from countries employing lower shares of imported inputs.

We acknowledge that our results come from reduced-form regression analyses, exploiting historical variations in weather and agricultural TFPs. Therefore, the analysis focuses on the impact of weather shocks on a particular aspect of the economies - agricultural TFP - and the

\footnotetext{
${ }^{33}$ One may concern about multicollinearities between the dummy variable on the share of imported inputs, $D_{i}^{\text {LowIm }}$, and the dummies $D_{i}^{\text {LowAggIm }}, D_{i}^{\text {LowGDPpc }}$, and $D_{i}^{\text {LowTFP }}$, leading to an unreliable regression result. However, correlation between these dummies is low. Based on the sample of 30 LICs, $\operatorname{Corr}\left(D_{i}^{\text {LowIm }}, D_{i}^{\text {Low AggIm }}\right)=$ $-0.0455, \operatorname{Corr}\left(D_{i}^{\text {LowIm }}, D_{i}^{\text {LowGDPpc }}\right)=0.3030$, and $\operatorname{Corr}\left(D_{i}^{\text {LowIm }}, D_{i}^{\text {LowTFP }}\right)=-0.0318$. Therefore, there is no issue arising from multicollinearities between these dummies.

${ }^{34}$ The dummy variable capturing countries' propensity to import in general is based on the share of total imports in goods and services to GDP obtained from the WDI. The dummy variable on the initial income levels is based on GDP per capita (constant US dollars) retrieved from the WDI. The dummy variable on the initial agricultural TFP is constructed using our TFP estimates.
} 
estimated impacts are considered as the short-run effects because we estimate countries' contemporaneous responses to short-run fluctuations in weather. In this sense, our analysis differs from ones in natural science fields employing estimates of future climate change and a General Circulation Model (GCM). These studies tend to find more pessimistic projections regarding the impact of climate change in the future. See Dell et al. (2014) and Auffhammer (2018) for more details.

\section{Counterfactuals}

The last set of analyses examines the magnitude of estimated impacts of imported inputs and weather shocks. Our analysis is simple. First, we estimate the regression $\ln \left(T F P_{i, t}\right)=\beta_{0}+$ $\beta_{1}$ Inputs $_{i, t}+\mathbb{X}_{i, t} \boldsymbol{\beta}_{2}+e_{i, t}$ with our baseline model using IV. Second, we find counterfactual TFP levels, keeping Inputs $_{i, t}$ at their 1991 level, $\hat{y}_{i, t}^{1991}=\hat{\beta}_{0}+\hat{\beta}_{1}$ Inputs $_{i, 1991}+\mathbb{X}_{i, t} \widehat{\boldsymbol{\beta}}_{2}+\hat{e}_{i, t} \cdot{ }^{35}$ Third, the gap between the counterfactual TFP and the actual TFP is computed $\operatorname{Gap}_{i, t}^{1991}=$ $100 \times\left[\hat{y}_{i, t}^{1991}-\ln \left(T F P_{i, t}\right)\right]$, which is a percentage deviation from the actual TFP level. If the gap is positive, then it means that actual changes in the share of imported inputs worked to reduce agricultural TFP and vice versa. We use the regression coefficients from column (4) of Table 2 to find counterfactual TFPs.

Figure 7: Counterfactual TFPs without Change in the Share of Imported Inputs since 1991

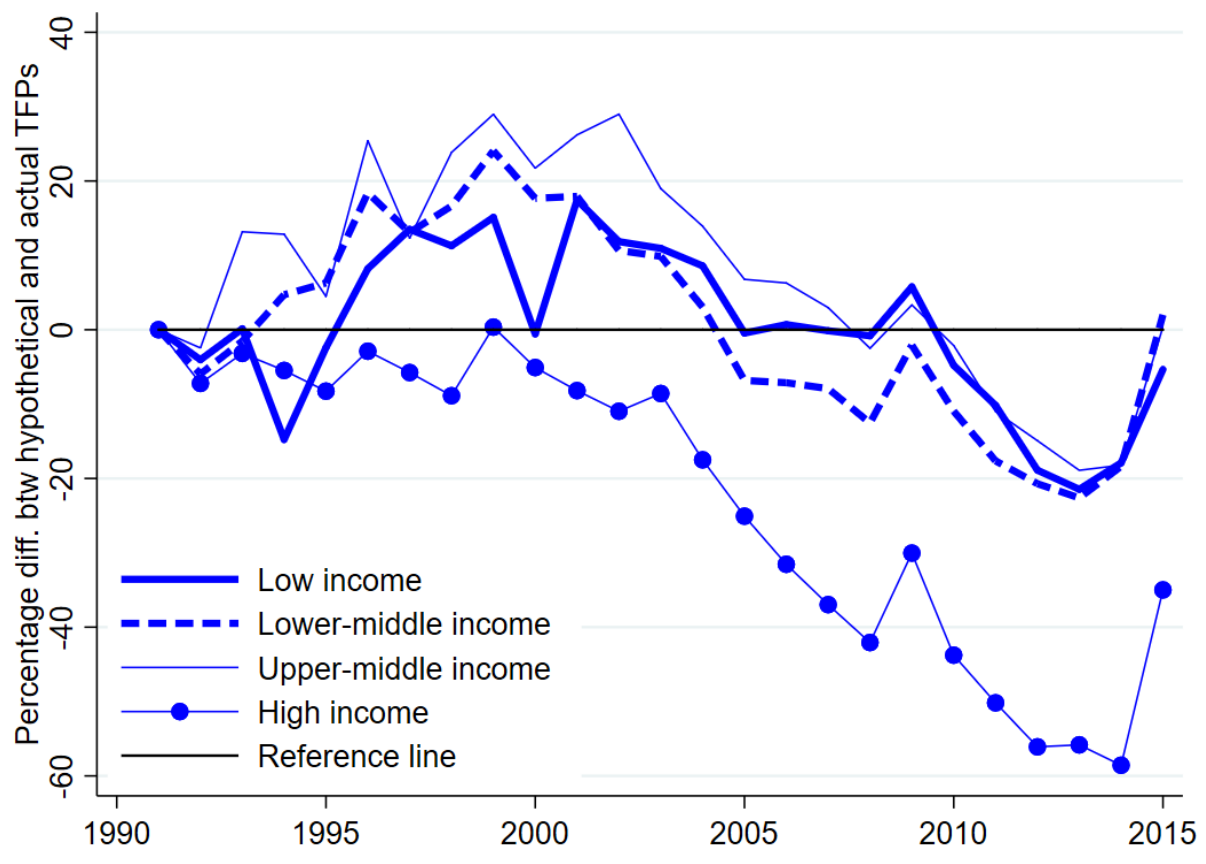

Notes: The figure shows percentage gaps between counterfactual TFP levels computed based on baseline regression result reported in column (4) of Table 2 and actual TFP levels, for the four groups of countries. Counterfactual TFP levels are estimated by assuming that the share of imported inputs did not change since 1991.

\footnotetext{
${ }^{35}$ Note that even residuals $\hat{e}_{i, t}$ are added to find counterfactuals because the purpose of this analysis is to isolate the impact of changes in the share of imported inputs.
} 
Figure 7 shows the estimated gap between counterfactual TFPs and actual TFPs for the four groups of countries. It shows that changes in the share of imported inputs in the 1990s worked to reduce agricultural TFP in lower income countries. In 2002, for example, if the share of imported inputs stayed at the 1991 level, upper-middle income countries would have had 20 percent higher agricultural TFP and low-income and lower-middle income countries would have had 10 percent greater TFP than the actual TFP.

Figure 8: Counterfactual TFPs without Weather Shocks, LICs



Notes: The figure shows differences between actual TFP levels and counterfactual TFP levels for the three scenarios. The thinner solid line, the dashed line, and the thicker solid line are based on Scenario 1: No change in temperatures, Scenario 2: No change in rainfalls, and Scenario 3: No change in temperatures and rainfalls since 1991.

The gap between the counterfactual and actual TFPs turned to be negative around 2004 for lower-middle income countries, and around 2010 for LICs and upper-middle-income countries. In 2014, LICs and middle-income countries would have about 20 percent lower TFP if the share of imported inputs stayed at the 1991 level. These results come from the fact that the share of imported inputs was declining in 1990s and it started to increase in early 2000s as shown in Figure 3. For high-income countries, the share of imported inputs continuously increased throughout the period, which contributed to the increase in TFP by about 60 percent in 2014 .

We conduct a similar counterfactual analysis for weather shocks. First, we estimate equation (2) and find parameter estimates. Second, find counterfactual TFP growth rate when climatic conditions stayed at the 1991 level by assuming $d$. Temp $p_{i, t}=0$ and $d$. $\operatorname{Rain}_{i, t}=0$. Third, we find counterfactual TFP level in 1992, $\widehat{T F P}_{i, 1992}^{1991}$, by using the counterfactual TFP growth rate in 1992 and the actual TFP level in 1991: $\widehat{T F P}_{i, 1992}^{1991}=\left(1+\hat{g}_{i, 1992}^{T F P} / 100\right) \times T F P_{i, 1991}$ and then find 
TFP levels in the following years as follows: $\widehat{T F P}_{i, t}^{1991}=\left(1+\hat{g}_{i, t}^{T F P} / 100\right) \times T F P_{i, t-1}$ for $t=$ $1993,1994, \ldots, 2015$. Forth, the gap between the counterfactual TFP and actual TFP is computed $\operatorname{Gap}_{i, t}^{1991}=100 \times\left[\ln \left(\widehat{T F P}_{i, t}^{1991}\right)-\ln \left(T F P_{i, t}\right)\right]$, which is a percentage deviation from the actual TFP level.

Table 8: Actual Agricultural Value-Added and Counterfactual Value-Added under Scenario 1

\begin{tabular}{|c|c|c|c|c|c|c|}
\hline & & Year & $\begin{array}{c}\text { Actual } \\
\text { agricultural } \\
\text { value-added } \\
\text { (million USD) } \\
(1) \\
\end{array}$ & $\begin{array}{c}\text { Hypothetical } \\
\text { agricultural } \\
\text { value-added } \\
\text { (million USD) } \\
\text { (2) }\end{array}$ & $\begin{array}{c}\text { Difference, } \\
\text { (2) minus (1) } \\
\text { (million USD) } \\
(3)\end{array}$ & $\begin{array}{c}\text { Percentage } \\
\text { difference, } \\
{[(2)-(1)] /(1) \times 100} \\
(4)\end{array}$ \\
\hline Afghanistan & $\mathrm{AFG}$ & 2010 & 2,639 & 2,772 & 133 & $5.0 \%$ \\
\hline Burundi & BDI & 2005 & 456 & 471 & 14 & $3.2 \%$ \\
\hline Benin & BEN & 2010 & 1,388 & 1,420 & 32 & $2.3 \%$ \\
\hline Burkina Faso & BFA & 2010 & 2,530 & 2,587 & 58 & $2.3 \%$ \\
\hline Central African Rep. & CAF & 2010 & 660 & 675 & 15 & $2.3 \%$ \\
\hline Gambia, The & GMB & 2010 & 222 & 227 & 5 & $2.1 \%$ \\
\hline Haiti & HTI & 2015 & 902 & 918 & 16 & $1.7 \%$ \\
\hline Liberia & LBR & 2010 & 707 & 716 & 9 & $1.2 \%$ \\
\hline Madagascar & MDG & 2009 & 1,053 & 1,122 & 69 & $6.6 \%$ \\
\hline Mali & MLI & 2010 & 3,583 & 3,719 & 136 & $3.8 \%$ \\
\hline Malawi & MWI & 2010 & 1,545 & 1,594 & 49 & $3.2 \%$ \\
\hline Niger & NER & 2010 & 2,009 & 2,064 & 56 & $2.8 \%$ \\
\hline Nepal & NPL & 2010 & 3,193 & 3,319 & 126 & $3.9 \%$ \\
\hline Rwanda & RWA & 2010 & 1,258 & 1,288 & 30 & $2.4 \%$ \\
\hline Senegal & SEN & 2010 & 1,570 & 1,607 & 37 & $2.3 \%$ \\
\hline Sierra Leone & SLE & 2010 & 1,124 & 1,139 & 15 & $1.3 \%$ \\
\hline Syria & SYR & 2010 & 5,219 & 5,479 & 260 & $5.0 \%$ \\
\hline Chad & TCD & 2010 & 3,415 & 3,483 & 68 & $2.0 \%$ \\
\hline Togo & TGO & 2010 & 1,032 & 1,055 & 23 & $2.2 \%$ \\
\hline Tanzania & TZA & 2010 & 6,421 & 6,569 & 148 & $2.3 \%$ \\
\hline Uganda & UGA & 2010 & 3,297 & 3,413 & 117 & $3.5 \%$ \\
\hline Total & & & 44,223 & 45,636 & 1,413 & $3.2 \%$ \\
\hline
\end{tabular}

Notes: The table shows actual agricultural value added (million USD, constant 2005 prices) and counterfactual agricultural value added based on counterfactual TFPs estimated based on Scenario 1 for LICs. Some LICs are missing from the table due to data availability constraint.

Counterfactuals are found only for LICs where we find significant effects of weather shocks. We consider three scenarios. Scenarios 1 and 2 are the cases where temperatures and rainfalls did not change since 1991, respectively. Scenario 3 is when both temperatures and rainfalls did not change since 1991. Figure 8 shows results and suggests that weather shocks worked to reduce agricultural TFP in LICs. About 2 percent agricultural TFP were lost in 2005 and 2010 because these two years had the warmest average temperatures (NOAA National Centers for Environmental Information, 2011). The figure shows that the temperature effect is much more sizable than the rainfall effect. Scenario 1 (no change in temperatures) and Scenario 3 (no change 
in temperatures and rainfalls) imply similar results while Scenario 2 (no change in rainfalls) leads to a relatively smaller difference in actual TFP and hypothetical TFP.

In order to quantify its effects on agricultural value-added, we estimate hypothetical agricultural value-added based on counterfactuals under Scenario 1 (no change in temperatures). The hypothetical agricultural value-added is estimated by plugging the counterfactual TFP to the

Cobb-Douglas production function: $Y_{i, t}^{C}=A_{i, t}^{C}\left(K_{i t}\right)^{\alpha_{i t}^{K}}\left(L_{i t}\right)^{\alpha_{i t}^{L}}\left(T_{i t}\right)^{\alpha_{i t}^{T}}$. Table 8 presents results for each of LICs from the year where the difference between the actual value-added $Y_{i, t}$ and the hypothetical value-added $Y_{i, t}^{C}$ is the largest. In many LICs, damages from higher temperatures are the greatest mostly in the year 2010 because the global average temperature was the record high in the year.

In terms of absolute value, the largest losses in agricultural value-added come from Syria, Tanzania, and Mali - 260 million USD, 148 million USD, and 136 million USD agricultural value-added were lost, respectively. In terms of percentage, the largest losses are from Madagascar (6.6\%), Afghanistan (5.0\%), Syria (5.0\%), and Nepal (3.9\%). In LICs as a whole, 3.2 percent of total agricultural value-added, which is equivalent to 1.4 billion USD, were lost if we collect the largest damages throughout the sample period 1991-2015. These results suggest that rising temperatures have economically sizable effects on agricultural value-added.

\section{Conclusions}

This paper has estimated agricultural TFP for 162 countries from 1990 to 2015 and examined the determinants of TFP by focusing on the role of imported inputs and weather shocks. We have three major findings - (1) An increase in usage of imported inputs has a significant impact on the level of TFP; (2) rising temperatures and rainfall shortages negatively influenced the agricultural TFP growth rate; (3) within LICs, a greater share of imported inputs works to reduce the negative effects of weather shocks.

While these results may imply that an optimistic view on the impact of future climate change because importing inputs would help LICs to deal with negative effects of weather shocks. However, we once again acknowledge that our results come from reduced-form regressions relating annual TFP growth rates with short-run fluctuations in weather. Therefore, this paper is silent about the impact of future climate change, which is projected to lead to more severe rises in temperatures and more radical changes in precipitation patterns compared with historical variations in the last two decades.

We have also conducted counterfactual analyses to understand the economic magnitudes of these impacts. The results suggest that an increase in the share of imported inputs explain at most 60 percent of agricultural TFP in high-income countries and 20 percent of that in low-income and middle-income countries. The economic magnitude of the impact of weather shocks is also sizable. Our results suggest that, colleting the cumulative losses in the warmest years during the sample period, in total 3.2 percent of agricultural value-added, which is equivalent to 1.4 billion USD, were lost due to a rise in temperatures in LICs as a whole. 


\section{REFERENCES}

1. Adamopoulos, Tasso and Diego Restuccia (2018) "Geography and Agricultural Productivity: Cross-Country Evidence from Micro Plot-Level Data”, NBER Working Paper No. 24532.

2. Alene, Arega D. (2010) "Productivity Growth and the Effects of R\&D in African Agriculture," Agricultural Economics, Vol. 41, pp. 223-238.

3. Amiti, Mary and Jozef Konings (2007) "Trade Liberalization, Intermediate Inputs, and Productivity: Evidence from Indonesia," American Economic Review, Vol. 97, No. 5, pp. 1611-1638.

4. Auffhammer, Maximilian (2018) "Quantifying Economic Damages from Climate Change", Journal of Economic Perspectives, Vol. 32, No. 4, pp. 33-52.

5. Barrios, Salvador, Luisito Bertinelli and Eric Strobl (2010) "Trends in Rainfall and Economic Growth in Africa: A Neglected Cause of the African Growth Tragedy," Review of Economics and Statistics, Vol. 92, No. 2, pp. 350-366.

6. Burke, Marshall, Solomon M. Hsiang, and Edward Miguel (2015) "Global Non-linear Effect of Temperature on Economic Production," Nature, Vol. 527, pp 235-239.

7. Cameron, A. Colin, Jonah B. Gelbach, and Douglas L. Miller (2011) "Robust Inference with Multiway Clustering”, Journal of Business and Economic Statistics, Vol. 29, No. 2, pp. 239249.

8. Caselli, Francesco, Miklos Karen, Milan Lisicky, and Silvana Tenreyro (2015) "Diversification through Trade", NBER Working Paper No. 21498.

9. Cattaneo, Cristina and Giovanni Peri (2016) "The Migration Response to Increasing Temperatures", Journal of Development Economics, Vol. 122, September 2016, pp. 127-146.

10. Coelli, Tim J. and D. S. Prasada Rao (2005) "Total Factor Productivity Growth in Agriculture: A Malmquist Index Analysis of 93 Countries, 1980-2000”, Agricultural Economics, Vol. 32, No. s1, pp. 115-134.

11. Chevassus-Lozza, Emmanuelle, Carl Gaigne, Leo Le Mener (2013) "Does Input Trade Liberalization Boost Downstream Firm's Exports? Theory and Firm-Level Evidence”, Journal of International Economics, Vol. 90, No. 2, 391-402.

12. Craig, Barbara J., Philip G. Pardey and Johannes Roseboom (1997) "International Productivity Patterns: Accounting for Input Quality, Infrastructure and Research," American Journal of Agricultural Economics, Vol. 79, No. 4, pp. 1064-1076.

13. Dell, Melissa, Benjamin F. Jones and Benjamin A. Olken (2012) "Temperature Shocks and Economic Growth: Evidence from the Last Half Century," American Economic Journal: Macroeconomics, Vol. 4, No. 3, pp. 66-95.

14. Dell, Melissa, Benjamin F. Jones, and Benjamin A. Olken (2014) "What Do We Learn the Weather? The New climate-Economy Literature", Journal of Economic Literature, Vol. 52, No. 3, pp. 740-796.

15. Deschenes, Olivier and Michael Greenstone (2007) "The Economic Impacts of Climate Change: Evidence from Agricultural Output and Random Fluctuations in Weather," American Economic Review, Vol. 97, No. 1, pp. 354-385.

16. Eaton, Jonathan and Samuel Kortum (2002) "Technology, Geography, and Trade" Econometrica, Vol. 70, No. 5, pp. 1741-1779.

17. FAO (2018) FAOSTAT, available at http://faostat3.fao.org/home/E.

18. Freedom House (2018) Individual Country Ratings and Status, FIW 1973-2018, available at https://freedomhouse.org/report-types/freedom-world\#.VdjOtk3bL60. 
19. Gollin, Douglas and Richard Rogerson (2014) "Productivity, Transport Costs and Subsistence Agriculture”, Journal of Development Economics, Vol. 107, March 2014, pp. $38-48$.

20. Goldberg, P. Koujianou, Amit K. Khandelwa, Nina Pavcnik, Petia Topalova (2010) "Imported Intermediate Inputs and Domestic Product Growth: Evidence from India", Quarterly Journal of Economics, Vol. 125, No. 4, pp. 1727-1767.

21. Halpern, Laszlo, Miklos Koren, Adam Szeidl (2015) "Imported Inputs and Productivity", American Economic Review, Vol. 105, No. 12, pp. 3660-3703.

22. Herrendorf, Berthold, Christopher Herrington, and Ákos Valentinyi (2015) "Sectoral Technology and Structural Transformation," American Economic Journal: Macroeconomics, Vol. 7, No. 4, pp. 104-133.

23. Hsiang, Solomon M. and Amir Jina (2014) "The Causal Effect of Environmental Carastrophe on Long-Run Economic Growth: Evidence from 6,700 Tropical Cyclones”, NBER Working Paper No. 20352.

24. IMF (2017), "The Effects of Weather Shocks on Economic Activity: How Can Low-Income Countries Cope?" Chapter 3 in World Economic Outlook, October 2017, Washington D.C.: International Monetary Fund.

25. Jayachandran, Seema (2006) "Selling Labor Low: Wage Responses to Productivity Shocks in Developing Countries," Journal of Political Economy, Vol. 114, No. 3, pp. 538-575.

26. Kasahara, Hiroyuki and Joel Rodrigue (2008) "Does the Use of Imported Intermediates Increase Productivity? Plant-Level Evidence”, Journal of Development Economics, Vol. 87, No. 1, pp. 106-118.

27. Kurukulasuriya, Pradeep, Robert Mendelsohn, Rashid Hassan, James Benhin, Temesgen Deressa, Mbaye Diop, Helmy Mohamed Eid, K. Yerfi Fosu, Glwadys Gbetibouo, Suman Jain, Ali Mahamadou, Renneth Mano, Jane Kabubo-Mariara, Samia El-Marsafawy, Ernest Molua, Samiha Ouda, Mathieu Ouedraogo, Isidor Séne, David Maddison, S. Niggol Seo and Ariel Dinar (2006) "Will African Agriculture Survive Climate Change?" World Bank Economic Review, Vol. 20, No. 3, pp. 367-388.

28. Lenzen, Manfred, Keiichiro Kanemoto., Daniel Moran, and Arne Geschke (2012) "Mapping the Structure of the World Economy." Environmental Science \& Technology, Vol. 46, No. 15, pp 8374-8381.

29. Lenzen, Manfred, Daniel Moran, Keiichiro Kanemoto, Arne Geschke (2013) "Building Eora: A Global Multi-regional Input-Output Database at High Country and Sector Resolution.” Economic Systems Research, Vol. 25, No. 1, pp. 20-49.

30. Macours, Karen and Johan F. M. Swinnen (2000) "Causes of Output Decline in Economic Transition: The Case of Central and Eastern European Agriculture", Journal of Comparative Economics, Vol. 28, No. 1, pp. 172-206.

31. McArthur, John, W and Gordon C. McCord (2017), "Fertilizing Growth: Agricultural Inputs and Their Effects on Economic Growth," Journal of Development Economics, Vol. 127, July 2017, pp. 133-152.

32. Mendelsohn, Robert, Ariel Dinar and Apurva Sanghi (2001) "The Effect of Development on the Climate Sensitivity of Agriculture," Environment and Development Economics, Vol. 6, No. 1, pp. 85-101.

33. Mendelsohn, Robert, Ariel Dinar and Larry Williams (2006) "The Distributional Impact of Climate Change on Rich and Poor Countries," Environment and Development Economics, Vol. 11, No. 2, pp. 159-178. 
34. Moore, Frances C. and Delavane B. Diaz (2015) "Temperature Impacts on Economic Growth Warrant Stringent Mitigation Policy", Nature Climate Change, Vol. 5, No. 2, pp. 127-131.

35. NOAA National Centers for Environmental Information (2011) State of the Climate: Global Climate Report for Annual 2010, Published online January 2011, Retrieved on November 2, 2018 from https://www.ncdc.noaa.gov/sotc/global/201013

36. Olper, Alessandro, Daniele Curzi, and Valentina Raimondi (2017) "Imported Intermediate Inputs and Firms' Productivity Growth: Evidence from the Food Industry", Journal of Agricultural Economics, Vol. 68, No. 1, pp. 280-300.

37. Schlenker, Wolfran and Michael J. Roberts (2009) "Nonlinear Temperature Effects Indicate Severe Damages to U.S. Crop Yields Under Climate Change," Proceedings of the National Academy of Sciences of the United States of America, Vol. 106, No. 37, pp. 15594-15598.

38. Timmer, Marcel P., Erik Dietzenbacher, Bart Los, Robert Stehrer, and Gaaitzen de Vries (2015) "An Illustrated User Guide to the World Input-Output Database: the Case of Global Automotive Production”, Review of International Economics, Vol. 23, No. 3, pp. 575-605.

39. Timmer, Marcel P., Abdul Azeez Erumban, Bart Los, Robert Stehrer, and Gaaitzen de Vries (2014) "Slicing Up Global Value Chains", Journal of Economic Perspectives, Vol. 28, No. 2, pp. 99-118.

40. Timmer, Marcel P., Bart Los, Robert Stehrer, and Gaaitzen de Vries (2016) "An Anatomy of the Global Trade Slowdown based on the WIOD 2016 Release", GGDC Research Memorandum Number 162, University of Groningen.

41. Topalova, Petia, and Amit Khandelwal (2011) "Trade Liberalization and Firm Productivity: The Case of India", Review of Economics and Statistics, Vol. 93, No. 3, pp. 995-1009.

42. Wang, Jinxia, Robert Mendelsohn, Ariel Dinar, Jikun Huang, Scott Rozelle and Lijuan Zhang (2009) "The Impact of Climate Change on China's Agriculture," Agricultural Economics, Vol. 40, pp. 323-337.

43. World Bank (2018a) World Development Indicators, available at http://data.worldbank.org/data-catalog/world-development-indicators.

44. World Bank (2018b) Climate Change Knowledge Portal, available at http://data.worldbank.org/data-catalog/cckp-ensemble-projections. 


\section{Appendix \\ A. List of Countries}

We follow the World Bank's classification of income-level of countries. In a broader definition, lower-middle income and upper-middle countries are classified as middle-income countries.

\begin{tabular}{cll}
\multicolumn{3}{c}{ Low-income countries (LICs) } \\
\hline No. ISO & Country & Region \\
\hline 1 AFG & Afghanistan & South Asia \\
2 BDI & Burundi & Sub-Saharan Africa \\
3 BEN & Benin & Sub-Saharan Africa \\
4 BFA & Burkina Faso & Sub-Saharan Africa \\
5 CAF & Central African Rep. & Sub-Saharan Africa \\
6 COD & Congo, Dem. Rep. & Sub-Saharan Africa \\
7 ERI & Eritrea & Sub-Saharan Africa \\
8 ETH & Ethiopia & Sub-Saharan Africa \\
9 GIN & Guinea & Sub-Saharan Africa \\
10 GMB & Gambia, The & Sub-Saharan Africa \\
11 HTI & Haiti & Latin America \& Caribbean \\
12 LBR & Liberia & Sub-Saharan Africa \\
13 MDG & Madagascar & Sub-Saharan Africa \\
14 MLI & Mali & Sub-Saharan Africa \\
15 MOZ & Mozambique & Sub-Saharan Africa \\
16 MWI & Malawi & Sub-Saharan Africa \\
17 NER & Niger & Sub-Saharan Africa \\
18 NPL & Nepal & South Asia \\
19 RWA & Rwanda & Sub-Saharan Africa \\
20 SEN & Senegal & Sub-Saharan Africa \\
21 SLE & Sierra Leone & Sub-Saharan Africa \\
22 SYR & Syria & Middle East \& North Africa \\
23 TCD & Chad & Sub-Saharan Africa \\
24 TGO & Togo & Sub-Saharan Africa \\
25 TJK & Tajikistan & Europe \& Central Asia \\
26 TZA & Tanzania & Sub-Saharan Africa \\
27 UGA & Uganda & Sub-Saharan Africa \\
28 YEM & Yemen, Rep. & Middle East \& North Africa \\
\hline
\end{tabular}

\begin{tabular}{|c|c|c|}
\hline \multicolumn{3}{|c|}{ Lower-middle-income countries } \\
\hline No. ISO & Country & Region \\
\hline $1 \mathrm{AGO}$ & Angola & Sub-Saharan Africa \\
\hline $2 \mathrm{BGD}$ & Bangladesh & South Asia \\
\hline $3 \mathrm{BOL}$ & Bolivia & Latin America \& Caribbean \\
\hline $4 \mathrm{BTN}$ & Bhutan & South Asia \\
\hline $5 \mathrm{CIV}$ & Cote d'Ivoire & Sub-Saharan Africa \\
\hline $6 \mathrm{CMR}$ & Cameroon & Sub-Saharan Africa \\
\hline $7 \mathrm{COG}$ & Congo, Rep. & Sub-Saharan Africa \\
\hline $8 \mathrm{CPV}$ & Cabo Verde & Sub-Saharan Africa \\
\hline 9 DJI & Djibouti & Middle East \& North Africa \\
\hline $10 \mathrm{EGY}$ & Egypt, Arab Rep. & Middle East \& North Africa \\
\hline $11 \mathrm{GEO}$ & Georgia & Europe \& Central Asia \\
\hline 12 GHA & Ghana & Sub-Saharan Africa \\
\hline $13 \mathrm{HND}$ & Honduras & Latin America \& Caribbean \\
\hline $14 \mathrm{IDN}$ & Indonesia & East Asia \& Pacific \\
\hline $15 \mathrm{IND}$ & India & South Asia \\
\hline $16 \mathrm{KEN}$ & Kenya & Sub-Saharan Africa \\
\hline $17 \mathrm{KGZ}$ & Kyrgyz Republic & Europe \& Central Asia \\
\hline $18 \mathrm{KHM}$ & Cambodia & East Asia \& Pacific \\
\hline $19 \mathrm{LAO}$ & Lao PDR & East Asia \& Pacific \\
\hline 20 LKA & Sri Lanka & South Asia \\
\hline $21 \mathrm{LSO}$ & Lesotho & Sub-Saharan Africa \\
\hline 22 MAR & Morocco & Middle East \& North Africa \\
\hline $23 \mathrm{MDA}$ & Moldova & Europe \& Central Asia \\
\hline 24 MMR & Myanmar & East Asia \& Pacific \\
\hline $25 \mathrm{MNG}$ & Mongolia & East Asia \& Pacific \\
\hline $26 \mathrm{MRT}$ & Mauritania & Sub-Saharan Africa \\
\hline $27 \mathrm{NGA}$ & Nigeria & Sub-Saharan Africa \\
\hline $28 \mathrm{NIC}$ & Nicaragua & Latin America \& Caribbean \\
\hline 29 PAK & Pakistan & South Asia \\
\hline 30 PHL & Philippines & East Asia \& Pacific \\
\hline $31 \mathrm{PNG}$ & Papua New Guinea & East Asia \& Pacific \\
\hline $32 \mathrm{SLV}$ & El Salvador & Latin America \& Caribbean \\
\hline $33 \mathrm{STP}$ & Sao Tome and Principe & Sub-Saharan Africa \\
\hline $34 \mathrm{SWZ}$ & Swaziland & Sub-Saharan Africa \\
\hline 35 TUN & Tunisia & Middle East \& North Africa \\
\hline $36 \mathrm{UKR}$ & Ukraine & Europe \& Central Asia \\
\hline $37 \mathrm{UZB}$ & Uzbekistan & Europe \& Central Asia \\
\hline $38 \mathrm{VNM}$ & Vietnam & East Asia \& Pacific \\
\hline $39 \mathrm{VUT}$ & Vanuatu & East Asia \& Pacific \\
\hline $40 \mathrm{ZMB}$ & Zambia & Sub-Saharan Africa \\
\hline
\end{tabular}




\section{Upper-middle-income countries}

\begin{tabular}{|c|c|c|}
\hline $\begin{array}{ll}\text { No. } & \text { ISO }\end{array}$ & Country & Region \\
\hline $1 \mathrm{ALB}$ & Albania & Europe \& Central Asia \\
\hline 2 ARM & Armenia & Europe \& Central Asia \\
\hline 3 AZE & Azerbaijan & Europe \& Central Asia \\
\hline $4 \mathrm{BGR}$ & Bulgaria & Europe \& Central Asia \\
\hline $5 \mathrm{BIH}$ & Bosnia and Herzegovina & Europe \& Central Asia \\
\hline $6 \mathrm{BLR}$ & Belarus & Europe \& Central Asia \\
\hline $7 \mathrm{BLZ}$ & Belize & Latin America \& Caribbean \\
\hline 8 BRA & Brazil & Latin America \& Caribbean \\
\hline 9 BWA & Botswana & Sub-Saharan Africa \\
\hline $10 \mathrm{CHN}$ & China & East Asia \& Pacific \\
\hline $11 \mathrm{COL}$ & Colombia & Latin America \& Caribbean \\
\hline $12 \mathrm{CRI}$ & Costa Rica & Latin America \& Caribbean \\
\hline $13 \mathrm{DOM}$ & Dominican Republic & Latin America \& Caribbean \\
\hline 14 DZA & Algeria & Middle East \& North Africa \\
\hline $15 \mathrm{ECU}$ & Ecuador & Latin America \& Caribbean \\
\hline $16 \mathrm{FJI}$ & Fiji & East Asia \& Pacific \\
\hline $17 \mathrm{GAB}$ & Gabon & Sub-Saharan Africa \\
\hline 18 GTM & Guatemala & Latin America \& Caribbean \\
\hline 19 GUY & Guyana & Latin America \& Caribbean \\
\hline 20 IRN & Iran, Islamic Rep. & Middle East \& North Africa \\
\hline 21 IRQ & Iraq & Middle East \& North Africa \\
\hline $22 \mathrm{JAM}$ & Jamaica & Latin America \& Caribbean \\
\hline $23 \mathrm{JOR}$ & Jordan & Middle East \& North Africa \\
\hline $24 \mathrm{LBN}$ & Lebanon & Middle East \& North Africa \\
\hline $25 \mathrm{LBY}$ & Libya & Middle East \& North Africa \\
\hline $26 \mathrm{MDV}$ & Maldives & South Asia \\
\hline $27 \mathrm{MEX}$ & Mexico & Latin America \& Caribbean \\
\hline $28 \mathrm{MKD}$ & Macedonia, FYR & Europe \& Central Asia \\
\hline $29 \mathrm{MNE}$ & Montenegro & Europe \& Central Asia \\
\hline 30 MUS & Mauritius & Sub-Saharan Africa \\
\hline 31 MYS & Malaysia & East Asia \& Pacific \\
\hline 32 NAM & Namibia & Sub-Saharan Africa \\
\hline 33 PER & Peru & Latin America \& Caribbean \\
\hline 34 PRY & Paraguay & Latin America \& Caribbean \\
\hline 35 RUS & Russian Federation & Europe \& Central Asia \\
\hline 36 SUR & Suriname & Latin America \& Caribbean \\
\hline 37 THA & Thailand & East Asia \& Pacific \\
\hline 38 TKM & Turkmenistan & Europe \& Central Asia \\
\hline 39 TUR & Turkey & Europe \& Central Asia \\
\hline $40 \mathrm{VEN}$ & Venezuela, RB & Latin America \& Caribbean \\
\hline $41 \mathrm{WSM}$ & Samoa & East Asia \& Pacific \\
\hline $42 \mathrm{ZAF}$ & South Africa & Sub-Saharan Africa \\
\hline
\end{tabular}

High-income countries

\begin{tabular}{|c|c|c|}
\hline $\begin{array}{ll}\text { No. } & \text { ISO }\end{array}$ & Country & Region \\
\hline $1 \mathrm{ARG}$ & Argentina & Latin America \& Caribbean \\
\hline 2 AUS & Australia & East Asia \& Pacific \\
\hline 3 AUT & Austria & Europe \& Central Asia \\
\hline $4 \mathrm{BHS}$ & The Bahamas & Latin America \& Caribbean \\
\hline 5 BHR & Bahrain & Middle East \& North Africa \\
\hline $6 \mathrm{BRB}$ & Barbados & Latin America \& Caribbean \\
\hline $7 \mathrm{BEL}$ & Belgium & Europe \& Central Asia \\
\hline $8 \mathrm{BRN}$ & Brunei Darussalam & East Asia \& Pacific \\
\hline $9 \mathrm{CAN}$ & Canada & North America \\
\hline $10 \mathrm{CHL}$ & Chile & Latin America \& Caribbean \\
\hline $11 \mathrm{HRV}$ & Croatia & Europe \& Central Asia \\
\hline $12 \mathrm{CYP}$ & Cyprus & Europe \& Central Asia \\
\hline $13 \mathrm{CZE}$ & Czech Republic & Europe \& Central Asia \\
\hline $14 \mathrm{DNK}$ & Denmark & Europe \& Central Asia \\
\hline $15 \mathrm{EST}$ & Estonia & Europe \& Central Asia \\
\hline 16 FIN & Finland & Europe \& Central Asia \\
\hline 17 FRA & France & Europe \& Central Asia \\
\hline $18 \mathrm{DEU}$ & Germany & Europe \& Central Asia \\
\hline 19 GRC & Greece & Europe \& Central Asia \\
\hline $20 \mathrm{HKG}$ & Hong Kong SAR, China & East Asia \& Pacific \\
\hline $21 \mathrm{HUN}$ & Hungary & Europe \& Central Asia \\
\hline 22 ISL & Iceland & Europe \& Central Asia \\
\hline 23 IRL & Ireland & Europe \& Central Asia \\
\hline 24 ISR & Israel & Middle East \& North Africa \\
\hline 25 ITA & Italy & Europe \& Central Asia \\
\hline $26 \mathrm{JPN}$ & Japan & East Asia \& Pacific \\
\hline $27 \mathrm{KOR}$ & Korea, Rep. & East Asia \& Pacific \\
\hline $28 \mathrm{KWT}$ & Kuwait & Middle East \& North Africa \\
\hline 29 LVA & Latvia & Europe \& Central Asia \\
\hline $30 \mathrm{LTU}$ & Lithuania & Europe \& Central Asia \\
\hline 31 LUX & Luxembourg & Europe \& Central Asia \\
\hline 32 MLT & Malta & Middle East \& North Africa \\
\hline 33 NLD & Netherlands & Europe \& Central Asia \\
\hline 34 NZL & New Zealand & East Asia \& Pacific \\
\hline $35 \mathrm{NOR}$ & Norway & Europe \& Central Asia \\
\hline $36 \mathrm{OMN}$ & Oman & Middle East \& North Africa \\
\hline 37 PAN & Panama & Latin America \& Caribbean \\
\hline $38 \mathrm{POL}$ & Poland & Europe \& Central Asia \\
\hline 39 PRT & Portugal & Europe \& Central Asia \\
\hline 40 QAT & Qatar & Middle East \& North Africa \\
\hline $41 \mathrm{SAU}$ & Saudi Arabia & Middle East \& North Africa \\
\hline 42 SGP & Singapore & East Asia \& Pacific \\
\hline $43 \mathrm{SVK}$ & Slovak Republic & Europe \& Central Asia \\
\hline 44 SVN & Slovenia & Europe \& Central Asia \\
\hline 45 ESP & Spain & Europe \& Central Asia \\
\hline 46 SWE & Sweden & Europe \& Central Asia \\
\hline $47 \mathrm{CHE}$ & Switzerland & Europe \& Central Asia \\
\hline 48 TTO & Trinidad and Tobago & Latin America \& Caribbean \\
\hline 49 ARE & United Arab Emirates & Middle East \& North Africa \\
\hline $50 \mathrm{GBR}$ & United Kingdom & Europe \& Central Asia \\
\hline 51 USA & United States & North America \\
\hline $52 \mathrm{URY}$ & Uruguay & Latin America \& Caribbean \\
\hline
\end{tabular}




\section{B. Data Sources and Summary Statistics}

Data sources are summarized in the following table.

\begin{tabular}{|c|c|c|}
\hline Variables & Unit & Data sources \\
\hline $\begin{array}{l}\text { Agricultural value-added (Agriculture, Forestry, and } \\
\text { Fishing) }\end{array}$ & $\begin{array}{l}\text { Value USD, } 2005 \text { prices, } \\
\text { millions }\end{array}$ & FAOSTAT \\
\hline Gross Production Value (Agriculture, PIN) & $\begin{array}{l}\text { Value USD, Constant } \\
\text { 2004-2006, millions }\end{array}$ & FAOSTAT \\
\hline $\begin{array}{l}\text { Net Capital Stocks (Agriculture, Forestry and } \\
\text { Fishing) }\end{array}$ & $\begin{array}{l}\text { Value US\$, } 2005 \text { prices, } \\
\text { millions }\end{array}$ & FAOSTAT \\
\hline Population, total & Persons & WDI \\
\hline $\begin{array}{l}\text { Employment to population ratio, } 15+\text {, total } \\
\text { (modeled ILO estimate) }\end{array}$ & $\%$ of total population & WDI \\
\hline Employment in agriculture (modeled ILO estimate) & $\%$ of total employment & WDI \\
\hline Agricultural area & 1000 ha & FAOSTAT \\
\hline Value of imported inputs & Current USD & $\begin{array}{l}\text { The authors' calculation based on the } \\
\text { data from EORA }\end{array}$ \\
\hline Value of total intermediate inputs & Current USD & $\begin{array}{l}\text { The authors' calculation based on the } \\
\text { data from EORA }\end{array}$ \\
\hline Fertilizer consumption & $\begin{array}{l}\text { Kilograms per hectare of } \\
\text { arable land }\end{array}$ & WDI \\
\hline Pesticides (total use) & Tons of active ingredients & FAOSTAT \\
\hline $\begin{array}{l}\text { Value-added in the agricultural sector (EORA sector } \\
\text { 1) }\end{array}$ & Current USD & EORA Database \\
\hline $\begin{array}{l}\text { Subsidies on production in the agricultural sector } \\
\text { (EORA sector 1) }\end{array}$ & Current USD & EORA Database \\
\hline $\begin{array}{l}\text { Taxes on production in the agricultural sector } \\
\text { (EORA sector 1) }\end{array}$ & Current USD & EORA Database \\
\hline Capital-to-labor ratio (EORA sector 1) & $\begin{array}{l}\text { Current USD over current } \\
\text { USD }\end{array}$ & $\begin{array}{l}\text { The authors' calculation based on } \\
\text { the data from EORA }\end{array}$ \\
\hline $\begin{array}{l}\text { Political instability index (Freedom house index, } \\
\text { civil liberty) }\end{array}$ & Index, from 1 to 7 & Freedom House \\
\hline Tariff rate, applied, weighted mean, all products & $\%$ & WDI \\
\hline FDI inflows to Agriculture, Forestry and Fishing & $\begin{array}{l}\text { Value US\$, } 2005 \text { prices, } \\
\text { millions }\end{array}$ & FAOSTAT \\
\hline Real effective exchange rate index & Index, $2010=100$ & WDI \\
\hline Temperatures & Degree Celsius & $\begin{array}{l}\text { World Bank's Climate Change } \\
\text { Knowledge Portal }\end{array}$ \\
\hline Rainfalls & $\mathrm{mm}$ & $\begin{array}{l}\text { World Bank's Climate Change } \\
\text { Knowledge Portal }\end{array}$ \\
\hline Gross Domestic Product & Value USD, 2005 prices & FAO \\
\hline Oil rents & $\%$ of GDP & WDI \\
\hline IMF Commodity Price Index & Index, $2005=100$ & IMF \\
\hline
\end{tabular}


Table A1: Summary Statistics

\begin{tabular}{|c|c|c|c|c|c|}
\hline & Obs. & Mean & Std. Dev. & Min. & Max. \\
\hline \multicolumn{6}{|l|}{ Dependent variables } \\
\hline $\ln (\mathrm{TFP})$ & 3,914 & -0.02 & 1.06 & -3.89 & 3.72 \\
\hline $\ln \left(\mathrm{TFP}_{b}\right)$ & 4,114 & -0.52 & 0.88 & -3.79 & 2.02 \\
\hline $\ln$ (Value-added) & 4,774 & 7.02 & 2.16 & -0.35 & 12.94 \\
\hline TFP growth rate & 3,751 & 2.44 & 14.02 & -80.03 & 384.96 \\
\hline $\mathrm{TFP}_{b}$ growth rate & 3,943 & 1.85 & 10.32 & -71.17 & 197.92 \\
\hline Value-added growth rate & 4,747 & 2.35 & 10.91 & -80.78 & 167.06 \\
\hline \multicolumn{6}{|l|}{ Explanatory variables } \\
\hline Imported inputs/Total inputs $\times 100$ & 4,420 & 16.62 & 16.62 & 0.00 & 99.96 \\
\hline Fertilizer \& Pesticide & 1,957 & 0.31 & 0.52 & 0.00 & 5.25 \\
\hline Capital-to-labor ratio & 4,152 & 26.23 & 55.44 & 0.02 & 561.62 \\
\hline Taxes/Value-added $\times 100$ & 4,199 & 3.87 & 3.69 & 0.00 & 18.73 \\
\hline Subsidies/Value-added $\times 100$ & 4,199 & 3.08 & 6.74 & 0.00 & 50.81 \\
\hline Political instability index & 3,720 & 3.42 & 1.78 & 1 & 7 \\
\hline \multicolumn{6}{|l|}{ Instruments } \\
\hline Tariffs for all products & 2,919 & 7.36 & 10.62 & 0 & 421.50 \\
\hline Tariffs for manufacturing goods & 2,919 & 7.25 & 6.98 & 0 & 150.92 \\
\hline Tariffs for primary goods & 2,919 & 7.93 & 21.02 & 0 & 917.75 \\
\hline FDI/Value added $\times 100$ & 1,050 & 0.82 & 2.69 & -30.00 & 27.86 \\
\hline $\ln ($ Effective exchange rate/100 +1$)$ & 2,030 & 0.69 & 0.11 & 0.27 & 1.82 \\
\hline \multicolumn{6}{|l|}{ Climate variables } \\
\hline Average temperature in degree Celsius & 4,160 & 19.26 & 8.35 & -7.06 & 29.75 \\
\hline Average monthly rainfalls in $100 \mathrm{~mm}$ & 4,134 & 1.00 & 0.73 & 0.01 & 3.75 \\
\hline Yearly change in average temperature & 4,160 & 0.03 & 0.55 & -3.64 & 2.93 \\
\hline Yearly change in average monthly rainfalls & 4,134 & 0.00 & 0.22 & -1.35 & 1.99 \\
\hline \multicolumn{6}{|l|}{ Dummies for all countries } \\
\hline Hot country dummy & 4,160 & 0.50 & 0.50 & 0 & 1 \\
\hline Agricultural country dummy & 4,758 & 0.25 & 0.43 & 0 & 1 \\
\hline Oil producer dummy & 4,186 & 0.10 & 0.30 & 0 & 1 \\
\hline \multicolumn{6}{|l|}{ Dummies for low-income countries } \\
\hline Lower share of imported inputs dummy & 780 & 0.50 & 0.50 & 0 & 1 \\
\hline Lower total imports-to-GDP ratio dummy & 702 & 0.52 & 0.50 & 0 & 1 \\
\hline Lower income country dummy & 806 & 0.48 & 0.50 & 0 & 1 \\
\hline Lower TFP dummy & 650 & 0.48 & 0.50 & 0 & 1 \\
\hline
\end{tabular}

Notes: The table shows summary statistics of variables employed in the regression analyses. The authors' calculation. See the main text and Appendix B for data sources. 


\section{Growth Accounting Results}

This section provides tables showing growth accounting results presented in the main text.

Table A2: Growth Accounting Results, LICs, 1991-2015

\begin{tabular}{|c|c|c|c|c|c|c|}
\hline & & \multirow{2}{*}{$\begin{array}{l}\text { Value- } \\
\text { added }\end{array}$} & \multicolumn{4}{|c|}{ Decomposition } \\
\hline & & & TFP & $\begin{array}{c}\text { Capital } \\
\text { stock }\end{array}$ & $\begin{array}{c}\text { Employ } \\
\text { ment }\end{array}$ & $\begin{array}{c}\text { Land } \\
\text { area }\end{array}$ \\
\hline Mali & MLI & 7.69 & 3.49 & 2.21 & 1.71 & 0.29 \\
\hline Chad & $\mathrm{TCD}$ & 6.85 & 3.60 & 2.06 & 1.15 & 0.04 \\
\hline Liberia & LBR & 6.20 & 1.84 & 3.54 & 0.71 & 0.11 \\
\hline Burkina Faso & BFA & 6.00 & 3.95 & 3.38 & -1.33 & 0.00 \\
\hline Mozambique & MOZ & 5.25 & 1.68 & 2.81 & 0.70 & 0.05 \\
\hline Niger & NER & 4.70 & 3.46 & -0.03 & 0.28 & 0.99 \\
\hline Benin & $\mathrm{BEN}$ & 4.32 & 2.79 & 0.36 & 0.56 & 0.61 \\
\hline Rwanda & RWA & 3.87 & 2.97 & 0.69 & 0.25 & -0.04 \\
\hline Tanzania & TZA & 5.09 & -0.50 & 5.23 & 0.33 & 0.03 \\
\hline Guinea & GIN & 3.73 & 1.18 & 1.73 & 0.78 & 0.04 \\
\hline Yemen, Rep. & YEM & 3.67 & 2.39 & 1.15 & 0.13 & -0.01 \\
\hline Uganda & UGA & 3.29 & 0.99 & 1.05 & 1.04 & 0.21 \\
\hline Malawi & MWI & 3.25 & 1.98 & 0.10 & 0.81 & 0.36 \\
\hline Nepal & NPL & 3.05 & 2.41 & 0.29 & 0.36 & -0.01 \\
\hline Senegal & SEN & 2.68 & 2.51 & -0.85 & 1.02 & 0.00 \\
\hline Togo & TGO & 2.48 & 0.61 & 0.92 & 0.73 & 0.21 \\
\hline Gambia, The & GMB & 1.99 & 1.80 & -0.61 & 0.78 & 0.03 \\
\hline Congo, Dem. Rep. & COD & 1.59 & 1.61 & -1.04 & 1.01 & 0.01 \\
\hline Madagascar & MDG & 1.58 & 0.31 & 0.17 & 0.94 & 0.16 \\
\hline Sierra Leone & SLE & 0.61 & -0.45 & 0.16 & 0.52 & 0.38 \\
\hline Syria & SYR & 0.43 & -0.29 & 1.07 & -0.38 & 0.03 \\
\hline Afghanistan & $\mathrm{AFG}$ & -0.40 & 0.58 & -1.73 & 0.75 & 0.00 \\
\hline Central African Rep. & CAF & 0.18 & 0.00 & -0.30 & 0.46 & 0.02 \\
\hline Burundi & BDI & -0.04 & -0.14 & -0.36 & 0.51 & -0.05 \\
\hline Haiti & HTI & -0.80 & -0.27 & -0.84 & 0.14 & 0.17 \\
\hline
\end{tabular}

Notes: The table shows annualized average growth rates of each component over 24 years, 1991-2015. Countries' income levels are based on the World Bank's classification. See the main text for data sources. 
Table A3: Growth Accounting Results, Lower-Middle Income Countries, 1991-2015

\begin{tabular}{|c|c|c|c|c|c|c|}
\hline & & \multirow{2}{*}{$\begin{array}{l}\text { Value- } \\
\text { added }\end{array}$} & \multicolumn{4}{|c|}{ Decomposition } \\
\hline & & & TFP & $\begin{array}{c}\text { Capital } \\
\text { stock }\end{array}$ & $\begin{array}{c}\text { Employ } \\
\text { ment }\end{array}$ & $\begin{array}{c}\text { Land } \\
\text { area }\end{array}$ \\
\hline Angola & $\mathrm{AGO}$ & 6.65 & 4.50 & 0.36 & 1.76 & 0.03 \\
\hline Nigeria & NGA & 6.24 & 4.24 & 1.63 & 0.22 & 0.15 \\
\hline Myanmar & MMR & 6.21 & 3.09 & 3.29 & -0.40 & 0.23 \\
\hline Vietnam & VNM & 3.94 & 4.23 & 0.50 & -0.87 & 0.07 \\
\hline Lao PDR & LAO & 3.88 & 0.90 & 2.44 & 0.13 & 0.41 \\
\hline Cambodia & KHM & 3.78 & 2.04 & 2.12 & -0.61 & 0.23 \\
\hline Djibouti & DJI & 3.75 & 1.63 & 1.34 & 0.48 & 0.29 \\
\hline Nicaragua & NIC & 3.68 & 2.27 & 0.51 & 0.63 & 0.28 \\
\hline Ghana & GHA & 3.60 & 3.12 & -0.30 & 0.53 & 0.25 \\
\hline Cameroon & CMR & 3.54 & 1.81 & 0.86 & 0.79 & 0.07 \\
\hline Bangladesh & BGD & 3.51 & 1.58 & 2.23 & -0.16 & -0.14 \\
\hline Papua New Guinea & PNG & 3.49 & 2.28 & 2.52 & -1.30 & 0.00 \\
\hline Pakistan & PAK & 3.24 & 1.89 & 0.65 & 0.66 & 0.03 \\
\hline Egypt, Arab Rep. & EGY & 3.16 & 1.09 & 0.97 & 0.26 & 0.85 \\
\hline Sao Tome and Principe & STP & 3.14 & 2.77 & 0.39 & -0.21 & 0.20 \\
\hline Indonesia & IDN & 3.09 & 2.61 & 0.21 & -0.32 & 0.58 \\
\hline India & IND & 3.01 & 1.68 & 1.60 & -0.26 & 0.00 \\
\hline Honduras & HND & 3.00 & 2.06 & 0.49 & 0.51 & -0.06 \\
\hline Congo, Rep. & $\mathrm{COG}$ & 2.98 & 1.92 & -0.08 & 1.13 & 0.01 \\
\hline Sri Lanka & LKA & 2.95 & 2.44 & 0.81 & -0.49 & 0.19 \\
\hline Vanuatu & VUT & 2.91 & -0.02 & 2.01 & 0.67 & 0.25 \\
\hline Bolivia & BOL & 2.76 & 2.14 & 0.47 & 0.11 & 0.04 \\
\hline Kenya & KEN & 2.59 & 0.58 & 0.87 & 1.14 & 0.00 \\
\hline Morocco & MAR & 2.45 & 0.62 & 1.45 & 0.37 & 0.01 \\
\hline Tunisia & TUN & 2.42 & 1.90 & 1.02 & -0.55 & 0.06 \\
\hline Bhutan & BTN & 2.41 & 1.06 & 1.27 & 0.07 & 0.00 \\
\hline Philippines & PHL & 2.27 & 1.84 & 0.16 & 0.08 & 0.18 \\
\hline Cabo Verde & $\mathrm{CPV}$ & 2.16 & -0.45 & 2.10 & 0.32 & 0.18 \\
\hline Mauritania & MRT & 1.99 & 0.85 & 0.31 & 0.83 & 0.00 \\
\hline Cote d'Ivoire & CIV & 1.87 & 1.83 & -0.61 & 0.46 & 0.18 \\
\hline El Salvador & SLV & 1.52 & 1.89 & 0.22 & -0.72 & 0.14 \\
\hline Lesotho & LSO & 1.44 & 2.89 & 1.09 & -2.52 & -0.02 \\
\hline Mongolia & MNG & 1.26 & 0.21 & 1.42 & -0.10 & -0.28 \\
\hline Swaziland & SWZ & 0.28 & 0.18 & -0.28 & 0.39 & 0.00 \\
\hline Zambia & $\mathrm{ZMB}$ & 0.26 & -0.44 & -0.20 & 0.74 & 0.16 \\
\hline
\end{tabular}

Notes: The table shows annualized average growth rates of each component over 24 years, 1991-2015. Countries' income levels are based on the World Bank's classification. See the main text for data sources. 
Table A4: Growth Accounting Results, Upper-Middle Income Countries, 1991-2015

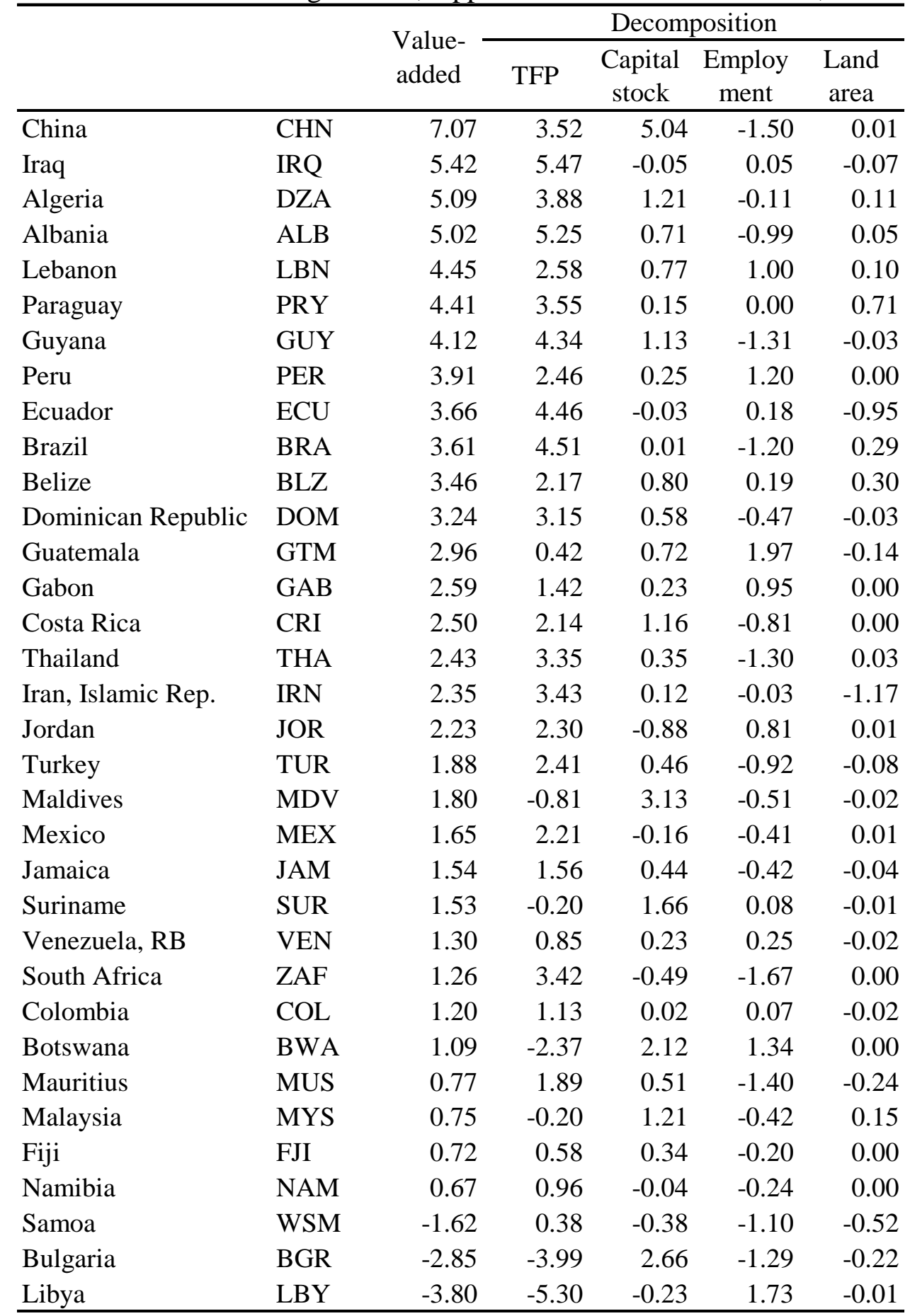

Notes: The table shows annualized average growth rates of each component over 24 years, 1991-2015. Countries' income levels are based on the World Bank's classification. See the main text for data sources. 
Table A5: Growth Accounting Results, High Income Countries, 1991-2015

\begin{tabular}{|c|c|c|c|c|c|c|}
\hline & & \multirow{2}{*}{$\begin{array}{l}\text { Value- } \\
\text { added }\end{array}$} & \multicolumn{4}{|c|}{ Decomposition } \\
\hline & & & TFP & $\begin{array}{c}\text { Capital } \\
\text { stock }\end{array}$ & $\begin{array}{c}\text { Employ } \\
\text { ment }\end{array}$ & $\begin{array}{c}\text { Land } \\
\text { area }\end{array}$ \\
\hline Kuwait & KWT & 10.68 & 8.92 & 0.90 & 0.84 & 0.02 \\
\hline Chile & $\mathrm{CHL}$ & 4.52 & 5.59 & 0.00 & -1.07 & 0.00 \\
\hline Oman & OMN & 3.93 & 2.35 & 0.56 & 0.79 & 0.23 \\
\hline Qatar & QAT & 3.88 & 1.79 & 1.75 & 0.32 & 0.01 \\
\hline Brunei Darussalam & BRN & 3.23 & 3.00 & 1.12 & -1.19 & 0.31 \\
\hline Bahrain & BHR & 3.03 & 1.06 & 1.55 & 0.40 & 0.02 \\
\hline Norway & NOR & 3.00 & 4.67 & -0.43 & -1.23 & 0.00 \\
\hline Australia & AUS & 2.97 & 2.48 & 1.19 & -0.63 & -0.07 \\
\hline Denmark & DNK & 2.69 & 3.92 & -0.10 & -1.13 & 0.00 \\
\hline Israel & ISR & 2.27 & 3.81 & 0.36 & -1.90 & 0.00 \\
\hline Panama & PAN & 2.24 & 1.42 & 0.51 & 0.23 & 0.08 \\
\hline United States & USA & 2.17 & 1.80 & 1.07 & -0.70 & 0.00 \\
\hline United Arab Emirates & ARE & 2.13 & 3.96 & 0.80 & -2.87 & 0.24 \\
\hline New Zealand & NZL & 2.04 & 1.14 & 1.41 & -0.29 & -0.22 \\
\hline Argentina & ARG & 1.88 & -0.59 & 0.71 & 1.61 & 0.14 \\
\hline Uruguay & URY & 1.84 & -1.63 & 1.95 & 1.57 & -0.05 \\
\hline Saudi Arabia & SAU & 1.52 & 2.20 & -1.54 & 0.71 & 0.15 \\
\hline Korea, Rep. & KOR & 1.46 & 4.24 & 0.27 & -3.06 & 0.00 \\
\hline France & FRA & 1.33 & 3.56 & 0.00 & -2.22 & 0.00 \\
\hline Austria & AUT & 1.26 & 0.86 & 0.74 & -0.33 & 0.00 \\
\hline Canada & CAN & 1.21 & 2.26 & 0.17 & -1.17 & -0.05 \\
\hline Finland & FIN & 1.01 & 2.57 & -0.42 & -1.14 & 0.00 \\
\hline United Kingdom & GBR & 0.67 & 1.08 & 0.78 & -1.16 & -0.04 \\
\hline Sweden & SWE & 0.67 & 1.10 & 0.53 & -0.96 & 0.00 \\
\hline Iceland & ISL & 0.29 & 0.90 & 0.54 & -1.15 & 0.00 \\
\hline Portugal & PRT & 0.08 & 1.13 & 0.86 & -1.91 & 0.00 \\
\hline Spain & ESP & -0.09 & 1.90 & -0.09 & -1.87 & -0.03 \\
\hline Italy & ITA & -0.19 & 2.17 & -0.01 & -2.35 & 0.00 \\
\hline Japan & JPN & -0.19 & 1.05 & -0.16 & -0.84 & -0.25 \\
\hline Malta & MLT & -0.39 & -0.19 & 0.91 & -1.11 & 0.00 \\
\hline Ireland & IRL & -0.39 & 0.29 & 0.12 & -0.81 & 0.00 \\
\hline Greece & GRC & -0.67 & -0.63 & 1.06 & -1.11 & 0.00 \\
\hline Netherlands & NLD & -0.73 & -1.45 & 1.29 & -0.57 & 0.00 \\
\hline Switzerland & $\mathrm{CHE}$ & -0.74 & -0.34 & -0.18 & -0.22 & 0.00 \\
\hline Cyprus & CYP & -0.79 & -0.21 & -0.01 & -0.33 & -0.25 \\
\hline Barbados & $\mathrm{BRB}$ & -1.18 & 0.62 & -0.79 & -0.66 & -0.35 \\
\hline Trinidad and Tobago & TTO & -1.41 & 0.12 & 0.00 & -1.32 & -0.21 \\
\hline Bahamas, The & BHS & -1.42 & -2.85 & 0.97 & 0.21 & 0.25 \\
\hline Singapore & SGP & -1.69 & -7.10 & -0.48 & 5.97 & -0.07 \\
\hline Germany & DEU & -2.72 & -0.66 & 0.31 & -2.38 & 0.00 \\
\hline Hong Kong SAR, China & HKG & -4.87 & -0.99 & -0.18 & -3.43 & -0.27 \\
\hline
\end{tabular}

Notes: The table shows annualized average growth rates of each component over 24 years, 1991-2015. Countries' income levels are based on the World Bank's classification. See the main text for data sources. 


\section{Estimating Agricultural TFP \\ D.1 Factor Shares}

We obtain data on labor compensation and capital compensation from the EORA database. It provides data on payments to capital (consumption of fixed capital), payments to labor (compensation of labor), and value-added. The capital shares are estimated as $\alpha_{i, t}^{K}=$

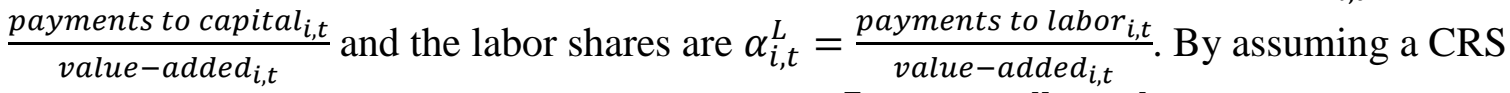
production technology, land shares are found as $\alpha_{i, t}^{T}=1-\alpha_{i, t}^{K}-\alpha_{i, t}^{L}$.

Table A6 summarizes average values of factor shares for four groups of countries in 1990 and 2015. These computations lead to reasonable numbers.

Table A6: Average Capital Shares, Labor Shares, and Land Shares

\begin{tabular}{|c|c|c|c|c|c|c|}
\hline & \multicolumn{3}{|c|}{1990} & \multicolumn{3}{|c|}{2015} \\
\hline & $\begin{array}{l}\text { Capital } \\
\text { share }\end{array}$ & $\begin{array}{l}\text { Labor } \\
\text { share }\end{array}$ & $\begin{array}{l}\text { Land } \\
\text { share }\end{array}$ & $\begin{array}{l}\text { Capital } \\
\text { share }\end{array}$ & $\begin{array}{l}\text { Labor } \\
\text { share }\end{array}$ & $\begin{array}{l}\text { Land } \\
\text { share }\end{array}$ \\
\hline Low income countries & 0.397 & 0.338 & 0.265 & 0.417 & 0.307 & 0.276 \\
\hline Lower-middle income countries & 0.300 & 0.416 & 0.284 & 0.305 & 0.399 & 0.297 \\
\hline Upper-middle income countries & 0.298 & 0.408 & 0.294 & 0.316 & 0.379 & 0.305 \\
\hline High income countries & 0.376 & 0.510 & 0.114 & 0.387 & 0.499 & 0.114 \\
\hline
\end{tabular}

Notes: The authors' calculation based on the data from the EORA.

\section{D.2 Estimating Cobb-Douglas Production Function}

Our baseline TFP estimates use factor share parameters calculated using the data from the EORA. We also provide alternative measure of TFP using factor share parameters obtained by estimating a Cobb-Douglas production, which we call $\mathrm{TFP}_{b}$. This section discusses how the parameters are estimated and presents estimation results.

We assume a Cobb-Douglas agricultural production function:

$$
Y_{i, t}=A_{i, t} K_{i, t}^{\alpha_{K}} L_{i, t}^{\alpha_{L}} T_{i, t}^{\alpha_{T}}
$$

where $Y_{i, t}$ denotes agricultural value-added of country $i$ in year $t ; A_{i, t}, K_{i, t}, L_{i, t}, T_{i, t}$ are agricultural TFP, capital stock, labor employment, and land area, respectively. $\alpha_{K}, \alpha_{L}$ and $\alpha_{T}$ are the shares of capital, labor, and land, respectively. The production function exhibits constant returns to scale (CRS), therefore $\alpha_{K}+\alpha_{L}+\alpha_{T}=1$.

By dividing the both sides by $L_{i, t}$, we can express the production function in intensive form as:

$$
\tilde{Y}_{i, t}=A_{i, t} \widetilde{K}_{i, t}^{\alpha_{K}} \widetilde{T}_{i, t}^{\alpha_{T}},
$$

where tilde indicate "per worker" $-\tilde{Y}_{i, t}=Y_{i, t} / L_{i, t}, \widetilde{K}_{i, t}=K_{i, t} / L_{i, t}$, and $\widetilde{T}_{i, t}=T_{i, t} / L_{i, t}$. This production function is transformed to a linear form by taking natural logs:

$$
\ln \left(\tilde{Y}_{i, t}\right)=\ln \left(A_{i, t}\right)+\alpha_{K} \ln \left(\widetilde{K}_{i, t}\right)+\alpha_{T} \ln \left(\widetilde{T}_{i, t}\right) \text {. }
$$

The labor share is obtained by exploiting the CRS assumption: $\alpha_{L}=1-\alpha_{K}-\alpha_{T}$. This structural equation could in principle be estimated using the panel data from all 170 countries available in the sample. Nevertheless, the matched data with other variables in the regression leads to a sample of 162 countries only, and the balanced panel dataset between 1991 and 2015 is only available for 144 countries. 
Table A7 presents estimated input shares with the Cobb-Douglas assumption. It shows that the capital share is 0.378 and the land share is 0.521 . The CRS assumption implies that the labor share is $1-\alpha_{K}-\alpha_{T}=0.100$.

Table A7: Growth Accounting Results, by Income-Levels of Countries, 1991-2015

\begin{tabular}{rc}
\hline & $(1)$ \\
\hline$\alpha_{K}$ & $0.378^{* * *}$ \\
& $(0.062)$ \\
$\alpha_{T}$ & $0.521^{* * *}$ \\
& $(0.097)$ \\
\hline Observations & 4,114 \\
Countries & 170 \\
\hline$R$-squared & 0.585 \\
$F$-statistic & 211.15 \\
$p$-value of $F$-statistic & 0.000 \\
\hline Labor share by assuming CRS \\
$1-\alpha_{K}-\alpha_{T}$ & $0.100^{*}$ \\
& $(0.056)$ \\
\hline
\end{tabular}

Notes: The table reports the result from estimating countries' agricultural production functions. The regression includes a constant term and country fixed effects. Standard errors, clustered at the country-level, are in parentheses.

\section{E. Level Effects and Growth Effects}

\section{E.1 The effect on the level of TFP}

We estimate the effect of imported inputs on the level of TFP by closely following empirical specifications in the literature on determinants of TFP (e.g., Alene, 2010; Craig et al., 1997; Amiti and Konings, 2007; Olper et al., 2017). They implicitly assume that agricultural production function of country $i$ of year $t$ is:

where

$$
Y_{i t}=A_{i t} K_{i t}^{\alpha_{K}} L_{i t}^{\alpha_{L}} T_{i t}^{\alpha_{T}}
$$

$$
A_{i t}=\exp \left(\mathbb{X}_{i t} \boldsymbol{\beta}+a_{i}+\varepsilon_{i t}\right) .
$$

The level of TFP $A_{i t}$ is a function of various factors in a vector $\mathbb{X}_{i t}$ and time-invariant country fixed effect $a_{i}$ and the error term $\varepsilon_{i t}$. By taking natural logs, we find

$$
\ln \left(A_{i t}\right)=\mathbb{X}_{i t} \boldsymbol{\beta}+a_{i}+\varepsilon_{i t},
$$

which is the regression equation we estimated in Section IV.

\section{E.2 The effect on the growth rate of TFP}

Equation (A.1) tests if regressors $\mathbb{X}_{i t}$ have the effect on the level of TFP. We allow weather shocks to affect the growth rate of TFP by closely following previous empirical studies on the effect of climate (Dell et al., 2012; Hsiang and Jina, 2014; Moore and Diaz, 2015; IMF, 2017). We explain a simple theoretical background following Dell et al. (2014).

The evolution of TFP is written as:

$$
A_{i t}=A_{i t-1} \exp \left(D_{i t}\right),
$$


where $D_{i t}$ denotes a damage function of weather shocks in country $i$ of year $t$. Greater economic damages due to weather shocks are related with a smaller value of $D_{i t}$. The current level of TFP $A_{i t}$ depends upon the previous level of TFP $A_{i t-1}$ as well as damages from weather shocks described in the function $D_{i t}$. Weather shocks affect the current level of TFP by altering its growth path from the previous period.

Taking natural logs leads to:

$$
\ln \left(A_{i t}\right)=\ln \left(A_{i t-1}\right)+D_{i t} .
$$

We assume a linear functional form for the damage function, $D_{i t}=\gamma_{0}+\gamma_{1}$ d. Temp $p_{i t}+$ $\gamma_{2}$ d. Rainfalls $s_{i t}+u_{i t}$ where $d$. Temp $_{i t}$ and $d$. Rainfalls $s_{i t}$ are annual changes in average temperatures and average monthly rainfalls from the previous year; $u_{i t}$ denotes the error term; $\gamma_{0}, \gamma_{1}$, and $\gamma_{2}$ are parameters to be estiamted. Given this assumption and by re-arrainging the previous equation, we find:

$$
\ln \left(A_{i t}\right)-\ln \left(A_{i t-1}\right)=\gamma_{0}+\gamma_{1} \text { d. Temp } p_{i t}+\gamma_{2} \text { d. Rainfalls } \text { Rit }+u_{i t},
$$

which is the baseline regression model in Section $\mathrm{V}$.

Dell et al. (2012), Hsiang and Jina (2014), Moore and Diaz (2015), and IMF (2017) estiamte the effect of climate on GDP growth rates by implicitely building upon this theoretical background. We assume that a similar argument applies in the context of agricultural production and estimate the impact on agricultural TFP.

\section{F. Correlation between Temperatures and Rainfalls}

One may concern about a multicollinearity between temperatures and rainfalls. However, there is no strong correlation between these two variables. Table A8 shows correlations between the regressors used in the regression analysis: changes in temperatures and changes in rainfalls.

Table A8: Correlations between d.Temp and d.Rainfall

\begin{tabular}{lccccc}
\hline & \multicolumn{2}{c}{ All countries } & & \multicolumn{2}{c}{ Low-income countries } \\
\cline { 2 - 3 } \cline { 5 - 6 } & $1970-2015$ & $1990-2015$ & & $1970-2015$ & $1990-2015$ \\
\hline Correlation coefficient & -0.0860 & -0.0885 & & -0.1512 & -0.0959 \\
Observations & 7,110 & 3,950 & & 1,170 & 650 \\
\hline
\end{tabular}

Notes: The authors' estimation.

It shows that there is virtually no correlation between the two variables. Using a sample of all countries, the correlation coefficient is -0.0860 and -0.0885 for the period 1970-2015 and 19902015, respectively. Restricting the sample to LICs only leads to correlation coefficients of 0.1512 and -0.0959 , for 1970-2015 and 1990-2015, respectively, which are quite low. Therefore, there is no multicollinearity.

\section{G. Robustness Checks on the Interactive Effects}

This section presents robustness checks on the climate change mitigation effect of imported inputs. Table A9 summarizes results from six additional regressions concerning various possible critiques. All of these regressions use equation (3) in the main text and employ the sample of LICs only. 
Column (1) cuts observations with extreme temperature changes where these are defined as observations where $d$.Temp is greater than the $95^{\text {th }}$ percentile or less than the $5^{\text {th }}$ percentile of d.Temp among observations from LICs after 1991. Column (2) drops observations with extreme rainfall changes where these are defined using the same cutoffs for $d$.Rainfalls. Columns (3) cuts observations from both extreme temperature changes and extreme rainfall changes. None of these treatments changes our results qualitatively.

Column (4)-(6) now use the baseline sample but we change the way we construct the imported input dummy. In the regressions in the main text we use the data from 1991 to make the imported inputs dummy. However, in column (4), it is constructed based on the data on $\frac{\text { Imported inputs }}{\text { Total inputs }} 1995$ using the same threshold as for the baseline, the $50^{\text {th }}$ percentile. In column (5), the dummy variable is constructed based on the country mean of $\frac{\text { Imported inputs }}{\text { Total inputs }}$ during 1991-1995. Again, results are similar to our baseline results.

Column (6) introduces a continuous variable of $\frac{\text { Imported inputs }}{\text { Total inputs }}$ and its interaction term. Because countries with higher share of imported inputs are less sensitive to weather shocks, the coefficient of the interaction term $d$. Temp $\times \frac{\text { Imported inputs }}{\text { Total inputs }}$ is expected to have a positive sign and the one for changes in temperature, d.Temp, should be negative. We expect opposite signs for rainfall variables - the coefficient of the interaction term $d$. Rainfalls $\times \frac{\text { Imported inputs }}{\text { Total inputs }}$ expected to have a negative sign and the one for changes in temperature, d. Rainfalls, should be positive. Results are as expected. The results show that our baseline results are robust. 
Table A9: Weather Shocks and Imported Inputs, LICs, More Robustness Checks

\begin{tabular}{|c|c|c|c|c|c|c|}
\hline & $\begin{array}{l}\text { Dropping } \\
\text { extreme } \\
\text { changes in } \\
\text { d.Temp }\end{array}$ & $\begin{array}{l}\text { Dropping } \\
\text { extreme } \\
\text { changes in } \\
\text { d.Rain }\end{array}$ & $\begin{array}{l}\text { Dropping } \\
\text { extreme } \\
\text { changes in } \\
\text { d.Temp \& } \\
\text { d.Rain } \\
\end{array}$ & $\begin{array}{c}\text { Input } \\
\text { dummy } \\
\text { based on the } \\
\text { data from } \\
1995 \\
\end{array}$ & $\begin{array}{c}\text { Input } \\
\text { dummy } \\
\text { based on } \\
\text { mean during } \\
1991-1995 \\
\end{array}$ & $\begin{array}{l}\text { Continuous } \\
\text { input variable }\end{array}$ \\
\hline & $(1)$ & (2) & (3) & (4) & $(5)$ & $(6)$ \\
\hline \multirow[b]{2}{*}{ Lower share of imported inputs $\times$ d.Temperature } & $\begin{array}{c}-2.720 \\
(1.764)\end{array}$ & $\begin{array}{c}1.337 \\
(0.872)\end{array}$ & $\begin{array}{c}-2.903 * * * \\
(1.100)\end{array}$ & $\begin{array}{c}0.158 \\
(0.829)\end{array}$ & $\begin{array}{c}0.302 \\
(1.021)\end{array}$ & $\begin{array}{c}-2.831 * * * \\
(0.657)\end{array}$ \\
\hline & $\begin{array}{c}-3.458 * * \\
(1.586)\end{array}$ & $\begin{array}{c}-5.321 * * * \\
(0.926)\end{array}$ & $\begin{array}{c}-2.586 * * \\
(1.261)\end{array}$ & $\begin{array}{c}-4.405 * * * \\
(1.017)\end{array}$ & $\begin{array}{c}-4.409 * * * \\
(0.979)\end{array}$ & $\begin{array}{l}0.055^{*} \\
(0.029)\end{array}$ \\
\hline \multirow[b]{2}{*}{ Lower share of imported inputs $\times$ d.Rainfalls } & $\begin{array}{c}0.698 \\
(2.343)\end{array}$ & $\begin{array}{c}16.91 * * * \\
(6.417)\end{array}$ & $\begin{array}{c}18.71 * * * \\
(4.453)\end{array}$ & $\begin{array}{c}3.877 * * * \\
(0.735)\end{array}$ & $\begin{array}{c}4.383 * * * \\
(0.553)\end{array}$ & $\begin{array}{c}6.136 \\
(3.982)\end{array}$ \\
\hline & $\begin{array}{c}12.00 * * * \\
(3.777)\end{array}$ & $\begin{array}{c}3.769 \\
(10.150)\end{array}$ & $\begin{array}{c}3.930 \\
(7.929)\end{array}$ & $\begin{array}{c}3.072 \\
(6.892)\end{array}$ & $\begin{array}{c}1.500 \\
(5.501)\end{array}$ & $\begin{array}{l}-0.025 \\
(0.228)\end{array}$ \\
\hline Lower share of imported inputs dummy & $\begin{array}{r}-0.053 \\
(0.408) \\
\end{array}$ & $\begin{array}{r}0.125 \\
(0.849) \\
\end{array}$ & $\begin{array}{c}0.357 \\
(0.495) \\
\end{array}$ & $\begin{array}{r}-0.993 \\
(0.833) \\
\end{array}$ & $\begin{array}{c}-0.991 \\
(0.838) \\
\end{array}$ & $\begin{array}{r}-0.013 \\
(0.015) \\
\end{array}$ \\
\hline Observations & 499 & 513 & 459 & 557 & 557 & 557 \\
\hline Countries & 24 & 24 & 24 & 24 & 24 & 24 \\
\hline$R$-squared & 0.095 & 0.11 & 0.122 & 0.079 & 0.08 & 0.072 \\
\hline \multicolumn{7}{|l|}{ Linear combination of coefficients, Temperature effects } \\
\hline Lower share of imported inputs & $\begin{array}{c}-6.177 * * * \\
(1.247)\end{array}$ & $\begin{array}{c}-3.985 * * * \\
(0.792)\end{array}$ & $\begin{array}{c}-5.489 * * * \\
(1.238)\end{array}$ & $\begin{array}{c}-4.247 * * * \\
(1.003)\end{array}$ & $\begin{array}{c}-4.107 * * * \\
(0.819)\end{array}$ & \\
\hline \multicolumn{7}{|l|}{ Linear combination of coefficients, Rainfall effects } \\
\hline Lower share of imported inputs & $\begin{array}{c}12.70 * * * \\
(3.080)\end{array}$ & $\begin{array}{c}20.68 * * * \\
(5.266)\end{array}$ & $\begin{array}{c}22.64 * * * \\
(4.906)\end{array}$ & $\begin{array}{c}6.949 \\
(7.188)\end{array}$ & $\begin{array}{c}5.883 \\
(5.666)\end{array}$ & \\
\hline
\end{tabular}

Notes: All regressions include a constant term and use the observations from LICs only. Robust standard errors, clustered at the country-level, are in parentheses. Temperatures are in degrees Celsius and rainfalls are in units of $100 \mathrm{~mm}$ per month. ***,**, and * indicate statistical significance at the $1 \%, 5 \%$, and $10 \%$ level, respectively. See the main text for data sources. 